\title{
Vitamin D and multiple health outcomes: umbrella review of systematic reviews and meta-analyses of observational studies and randomised trials
}

\author{
Evropi Theodoratou research fellow ${ }^{1}$, Ioanna Tzoulaki lecturer ${ }^{23}$, Lina Zgaga associate professor ${ }^{4}$, \\ John P A loannidis professor ${ }^{56}$
}

${ }^{1}$ Centre for Population Health Sciences, University of Edinburgh, Edinburgh EH8 9AG, UK; ${ }^{2}$ Department of Epidemiology and Biostatistics, Imperial College London, London W2 1PG, UK; ${ }^{3}$ Department of Hygiene and Epidemiology, University of loannina School of Medicine, loannina 45110 , Greece; ${ }^{4}$ Department of Public Health and Primary Care, Trinity College Dublin, Dublin 24, Ireland; ${ }^{5}$ Stanford Prevention Research Center, Departments of Medicine and Health Research and Policy, Stanford University School of Medicine, Stanford, CA 94305-5411, USA; ${ }^{6}$ Department of Statistics, Stanford University School of Humanities and Sciences, Stanford

\begin{abstract}
Objective To evaluate the breadth, validity, and presence of biases of the associations of vitamin $D$ with diverse outcomes.

Design Umbrella review of the evidence across systematic reviews and meta-analyses of observational studies of plasma 25-hydroxyvitamin D or 1,25-dihydroxyvitamin D concentrations and randomised controlled trials of vitamin D supplementation.
\end{abstract}

Data sources Medline, Embase, and screening of citations and references.

Eligibility criteria Three types of studies were eligible for the umbrella review: systematic reviews and meta-analyses that examined observational associations between circulating vitamin D concentrations and any clinical outcome; and meta-analyses of randomised controlled trials assessing supplementation with vitamin $\mathrm{D}$ or active compounds (both established and newer compounds of vitamin D).

Results 107 systematic literature reviews and 74 meta-analyses of observational studies of plasma vitamin $\mathrm{D}$ concentrations and 87 meta-analyses of randomised controlled trials of vitamin D supplementation were identified. The relation between vitamin $\mathrm{D}$ and 137 outcomes has been explored, covering a wide range of skeletal, malignant, cardiovascular, autoimmune, infectious, metabolic, and other diseases. Ten outcomes were examined by both meta-analyses of observational studies and meta-analyses of randomised controlled trials, but the direction of the effect and level of statistical significance was concordant only for birth weight (maternal vitamin D status or supplementation). On the basis of the available evidence, an association between vitamin $\mathrm{D}$ concentrations and birth weight, dental caries in children, maternal vitamin $\mathrm{D}$ concentrations at term, and parathyroid hormone concentrations in patients with chronic kidney disease requiring dialysis is probable, but further studies and better designed trials are needed to draw firmer conclusions. In contrast to previous reports, evidence does not support the argument that vitamin D only supplementation increases bone mineral density or reduces the risk of fractures or falls in older people.

Conclusions Despite a few hundred systematic reviews and meta-analyses, highly convincing evidence of a clear role of vitamin D does not exist for any outcome, but associations with a selection of outcomes are probable.

\section{Introduction}

The associations between vitamin D concentrations and various conditions and diseases have been assessed in a large and rapidly expanding literature. In addition to observational studies, numerous randomised trials have examined the effect of vitamin D supplementation on a range of outcomes. Historically, vitamin $\mathrm{D}$ had been linked to skeletal disease including calcium, phosphorus, and bone metabolism, ${ }^{12}$ osteoporosis, ${ }^{3}$ fractures, ${ }^{45}$ muscle strength, ${ }^{6}$ and falls. ${ }^{7}$ In the 2000 s, growing scientific attention turned to non-skeletal chronic diseases as vitamin D deficiency was linked to cancer, ${ }^{8}$ cardiovascular diseases, ${ }^{9} 10$ metabolic disorders, ${ }^{11}$ infectious diseases, ${ }^{12}$ and autoimmune diseases,${ }^{13-15}$ as well as mortality. ${ }^{16}$ If causal, these associations might be of great importance for public health, as vitamin D deficiency has been found to be highly prevalent in populations residing at high latitudes or leading an indoors oriented lifestyle. ${ }^{17}$ However, the composite literature is often confusing and has led to heated debates about the optimal concentrations of vitamin D and related guidelines for supplementation. ${ }^{18-20}$ 
To provide an overview of the breadth and validity of the claimed associations of vitamin D with diverse outcomes, we have done an umbrella review of the evidence across existing systematic reviews and meta-analyses. We aimed to do a comprehensive evaluation of systematic reviews and meta-analyses of observational studies that examined associations of vitamin D concentrations with a range of clinical outcomes, as well as meta-analyses of randomised controlled trials of vitamin D supplementation. We also compared the findings of the observational studies with those from meta-analyses of randomised controlled trials of vitamin D supplementation, whenever these could be juxtaposed. We sought to summarise the health outcomes that have been associated with vitamin D concentrations, evaluate whether evidence exists of biases in this literature, identify health outcomes without evidence of biases, and examine the consistency of inferences from the meta-analyses of observational studies and of randomised controlled trials.

\section{Methods}

\section{Structure of umbrella review}

An umbrella review systematically collects and evaluates information from multiple systematic reviews and meta-analyses on all clinical outcomes for which these have been performed. ${ }^{21}$ Here, for evidence on observational associations between vitamin D concentrations and any health outcome, we sought to collect information from systematic reviews regardless of whether they also included quantitative syntheses (meta-analyses). Given the very large heterogeneity that may be encountered in observational studies, often meta-analysis may not be done in systematic reviews of observational studies, whereas this problem occurs much less frequently in systematic reviews of randomised controlled trials, for which meta-analysis is the norm, especially when interventions are drugs or vitamins. ${ }^{22}$ Where available, we also evaluated in more depth the quantitative results of the meta-analyses of observational associations and potential hints of bias in these meta-analyses. ${ }^{23-25}$ For evidence on randomised controlled trials of vitamin D supplementation, we considered only formal quantitative meta-analyses. We compared results from meta-analyses of observational studies and randomised controlled trials, whenever data were available for the same outcome.

\section{Search strategy}

Two reviewers (IT, ET) searched Medline and Embase in duplicate, using the search algorithm in supplementary table A, from inception to 11 October 2013 (last update) and limited the search to humans and English language, as the overwhelming majority of review studies are published in English language, peer reviewed journals. Any discrepancies were resolved with discussion. We firstly perused the title and abstract of each of these citations and then retrieved potentially eligible articles for perusal in full text.

\section{Eligibility criteria and appraisal of included studies}

Three types of studies were eligible for the umbrella review: observational associations between circulating vitamin D concentrations and any clinical outcome examined in systematic reviews, meta-analyses, or both; and meta-analyses of randomised controlled trials assessing supplementation of vitamin D or active compounds (both established and newer compounds of vitamin D). We excluded studies that examined genetic polymorphisms related to vitamin D metabolism (for example, vitamin D receptor); systematic reviews and meta-analyses of observational studies assessing dietary or supplementary vitamin D intake or ultraviolet B exposure; studies that had vitamin D status as the outcome; studies that investigated the prevalence of vitamin D deficiency in certain disease populations; and meta-analyses of randomised controlled trials in which the treatment arm combined vitamin D with calcium or other vitamins or compounds versus placebo. When the treatment arm and control arm included the same additional compound (for example vitamin $\mathrm{D}$ and calcium versus calcium), we included the meta-analysis in the review. We included meta-analyses regardless of the baseline characteristics (clinical setting or age) of the examined populations. If an article presented separate meta-analyses on more than one eligible outcome or type of clinical setting, we assessed those separately.

Appraisal of individual component studies was beyond the scope of this umbrella review. This was the aim of the original systematic reviews and meta-analyses, which should include an appraisal of studies' quality. In respect to the selected systematic reviews and meta-analyses, we used methods that captured essential features of the quality of the evidence, and these are described in detail in the data analysis section.

\section{Data extraction}

Three investigators (ET, IT, LZ) extracted data independently. From each eligible systematic review or meta-analysis, we abstracted the PubMed ID, first author, journal, year of publication, vitamin D biomarker, population, and outcome examined. From each systematic review of observational studies, we recorded a statement summarising the authors' main interpretations of their findings. From each meta-analysis of observational studies or randomised controlled trials, we further abstracted data on the studies included in the analysis: the study specific relative risk estimates (risk ratio, odds ratio, hazard ratio, or incident risk ratio, as reported by the authors of the meta-analysis), along with the corresponding confidence intervals and the number of cases and controls for each study. We categorised outcomes into the following categories: autoimmune diseases, cancer outcomes, cardiovascular outcomes, cognitive disorders, infectious diseases, metabolic disorders, neonatal/infant/child related outcomes, pregnancy related outcomes, skeletal outcomes (including falls), and "other" outcomes (supplementary table B).

\section{Data analysis}

We carried out descriptive analysis for systematic reviews. We categorised the conclusions of each systematic review for the association of vitamin $\mathrm{D}$ and the outcome of interest in one of the following four categories: definite association, suggestive (possible) association, no association, or inconclusive (insufficient) evidence. Whenever more than one systematic review had been performed on the same outcome, we examined whether the main reported conclusions were concordant. We retained the most recent systematic review for further analyses.

When we identified more than one meta-analysis of observational studies examining the association between a given vitamin D biomarker and outcome pair in the same clinical setting, we examined the conclusions for concordance regarding the direction, level of statistical significance (at $\mathrm{P} \leq 0.05$ ), and magnitude (overlapping confidence interval) of the association. Then, we again retained only the most recent meta-analysis with eligible data for further statistical analysis. We estimated the summary effect size and its confidence interval by using random 
effects models and calculated the $\mathrm{I}^{2}$ and its confidence interval metric for heterogeneity for each eligible meta-analysis that reported the effect sizes, number of cases, and total number of participants of the component studies. ${ }^{26}{ }^{27}$ We used the regression asymmetry test to test for small study effects. ${ }^{28}$ We also applied the excess significance test, which evaluates whether the observed number of studies with statistically significant results ("positive" studies) differs from the expected number of positive studies, by using a $\chi^{2}$ test. ${ }^{29-31}$ The expected number of positive studies for each meta-analysis is calculated by the sum of the statistical power estimates for each component study. We estimated the power of each study for an effect equal to the effect of the largest study (study with the smallest variance), as previously described. ${ }^{32} \mathrm{We}$ used appropriate equations to estimate the power, on the basis of whether the largest study reported a hazard ratio or an odds ratio. ${ }^{33}$ If the type of the metric was a standardised mean difference, we transformed this to an odds ratio before using it in the analysis.

Eight meta-analyses presented in five papers were not included in the excess significance bias analysis either because individual study data was unavailable ${ }^{35} 36$ or because it reported the logarithm of geometric mean ratio, ${ }^{37}$ the weighted mean difference, ${ }^{36}$ or the Fisher's z score ${ }^{38}$ Both the small study and excess significance tests were considered significant at $\mathrm{P}<0.10$, as previously proposed. ${ }^{23}$

We specifically identified outcomes for which meta-analyses of observational studies showed nominally significant associations (at $\mathrm{P} \leq 0.05$ ), did not have large between study heterogeneity, were based on evidence from more than 500 cases (or more than 5000 total participants if the type of metric was continuous), and showed no evidence of small study effects or excess significance. We also noted how many would satisfy the same criteria but with $\mathrm{P} \leq 0.001$, which has been considered to be a more appropriate threshold of statistical significance to reduce false positives. ${ }^{39-41}$

When we identified more than one meta-analysis of randomised controlled trials examining the relation between vitamin $\mathrm{D}$ supplementation and outcome pair in the same clinical setting, we examined the conclusions for concordance regarding the direction, level of statistical significance (at $\mathrm{P} \leq 0.05$ ), and magnitude (overlapping confidence interval) of the association.

When meta-analyses for the same outcome existed both for association studies of vitamin D concentrations and for randomised controlled trials of vitamin D supplementation, we compared their results in terms of whether a nominally statistically significant effect had been described $(\mathrm{P} \leq 0.05)$ and whether the effect estimate was in the same direction. We did not compare the magnitude of the effect sizes between circulating vitamin D concentrations and vitamin D supplementation, as these are difficult to translate to the same vitamin D concentration/treatment contrasts. Whenever no meta-analysis of observational studies existed for an outcome examined by a meta-analysis of randomised controlled trials, we compared the main results with the results of a systematic review of observational studies, if available. Finally, we applied a set of criteria to conclude whether the evidence for a given outcome was definite, probable, suggestive, not conclusive, or unlikely (see box).

We used Stata version 12.1 for statistical analyses. P values were two tailed.

\section{Results}

Overall, 1256 articles searched yielded 107 systematic reviews without meta-analyses (presented in 24 papers) ${ }^{36}{ }^{42-64}$ and 74 meta-analyses (47 papers) ${ }^{11}$ 35-38 52 65-105 of observational studies that investigated associations with circulating vitamin D concentrations. In addition, we identified and included 87 meta-analyses (32 papers) $)^{5737526170106-131}$ of randomised controlled trials of vitamin D supplementation (fig $1 \downarrow$; supplementary tables C-E). Across all three study types, results on 137 unique outcomes were reported (fig $2 \Downarrow$; supplementary table B).

\section{Vitamin D concentrations and health outcomes: systematic reviews of observational studies}

The median number of observational studies included in the systematic reviews was four (range 1-28) (supplementary table C). Among the 107 identified systematic reviews, 76 unique ones were presented in 21 papers (supplementary table B), ${ }^{36}{ }^{43-49} 52-64$ whereas more than one systematic review existed for 24 outcomes (in 15 of which the authors reached the same qualitative conclusion; supplementary table $\mathrm{C}$ ).

For only six (8\%) of the 76 unique outcomes, the systematic reviews concluded that a definite association existed (supplementary tables B and F). These were rheumatoid arthritis activity, colorectal cancer, hypertension in children, bacterial vaginosis in pregnant women, falls in older people, and rickets in children; for all these outcomes, higher concentrations of vitamin D were associated with lower risk. Conversely, for 10 (13\%) outcomes, the authors concluded that no association existed between the examined outcome and vitamin D status. For 60 of the 76 unique outcomes, the systematic reviews did not reach a firm, unequivocal conclusion: for $43(57 \%)$ authors reported that the reviewed data were inconclusive or insufficient to draw any firm conclusions, and 17 (22\%) found that an inverse association was possible or suggestive. No systematic reviews concluded that a definite or suggestive association existed for increased risk with higher concentrations of vitamin D.

\section{Vitamin D concentrations and health outcomes: meta-analyses of observational studies}

We identified 74 meta-analyses of observational studies (supplementary table D). Among these, 48 unique meta-analyses were presented in 28 papers (fig $1 \Downarrow$; supplementary table G). ${ }^{35-38} 6668717476787982-84868889919596$ 98-105 Forty three meta-analyses examined the link between vitamin D and outcome by using 25-hydroxyvitamin $\mathrm{D}$ and five by using 1,25-dihydroxyvitamin D. All meta-analyses reported estimates adjusted for a wide variety of other covariates. Meta-analyses examined a very wide range of outcomes including cancers $(n=20)$, cardiovascular diseases $(n=8)$, cognitive disorders $(n=4)$, metabolic disorders $(n=4)$, neonatal/infant/child related outcomes $(n=4)$, skeletal diseases $(n=3)$, pregnancy related outcomes $(n=2)$, infectious disease $(n=1)$, or other outcomes $(n=2)$ (supplementary table G). The median number of studies included was seven (range 2-37), the median number of participants was 5905 (39-82 982), and the median number of events was 1289 (18-15 447). Overall, 30 (63\%) of the 48 meta-analyses of observational studies reported a nominally statistically significant summary result (tables $1 \Downarrow$ and $2 \Downarrow$ ). Figure $3 \Downarrow$ shows a forest plot with the summary effects of all the non-overlapping meta-analyses of observational studies (for binary outcomes).

We found more than one published meta-analysis for 11 outcomes: Alzheimer's disease ( $\mathrm{n}=2$ meta-analyses), breast cancer $(n=6)$, colorectal adenoma $(n=3)$, colorectal cancer $(n=7)$, 


\section{Criteria for evidence categories}

Convincing - Evidence existed from both observational studies and randomised controlled trials (RCTs), and association/effect was of the same direction, statistically significant at $P \leq 0.001$, and free from bias

Probable - Evidence existed from both observational studies and RCTs, and association/effect was of the same direction and statistically significant at $P \leq 0.001$, but excess significance could not be tested; or evidence existed from RCTs and effect was statistically significant at $\mathrm{P} \leq 0.001$ and with no contrary results from observational data (that is, systematic reviews, if any exist, are also definitive or suggestive and meta-analyses of observational studies, if any exist, are in the same direction)

Suggestive - Evidence from RCTs with an effect at $0.001 \leq \mathrm{P} \leq 0.05$ and with no contrary results from observational data (same as above); or evidence from meta-analyses of observational studies showing an association at $\mathrm{P} \leq 0.001$, with no contrary results from randomised data (that is, meta-analysis of RCTs, if present, have effects in the same direction) and, if it could be tested, no evidence of small study effects $(P \geq 0.10)$, not very large heterogeneity $\left(l^{2} \leq 75 \%\right)$, no evidence for excess significance, based on cumulative evidence of more than $\mathbf{5 0 0}$ disease events (or more than $\mathbf{5 0 0 0}$ total participants if type of metric was continuous)

No conclusion—Not enough evidence from observational studies or RCTs to draw conclusion

Substantial effect unlikely —Evidence from observational studies or RCTs enough to conclude that a substantial effect is unlikely based on the magnitude and the significance level

cardiovascular diseases $(n=3)$, gestational diabetes $(n=2)$, hypertension $(n=3)$, prostate cancer $(n=4)$, stroke $(n=2)$, type 2 diabetes $(n=3)$, and prevalence of type 2 diabetes $(n=2)$. For all the outcomes, agreement existed between the meta-analyses on the direction, magnitude, and statistical significance of the association (supplementary table $\mathrm{H}$ ).

\section{Summary effects, heterogeneity, and bias tests for meta-analyses of observational associations}

Of the 48 non-overlapping meta-analyses of observational studies, the largest study had statistically significant results in $21(44 \%)$ meta-analyses (supplementary figure A). The largest study's result was more conservative than the summary result in $20(42 \%)$ meta-analyses. Fifteen $(31 \%)$ meta-analyses had large heterogeneity $\left(\mathrm{I}^{2}>50 \%\right)$, and seven $(15 \%)$ had very large heterogeneity $\left(\mathrm{I}^{2}>75 \%\right)$. Evidence for significant small study effects was noted in three meta-analyses (breast cancer, all cause mortality, and cardiovascular disease mortality) (tables $1 \Downarrow$ and $2 \Downarrow$ ). Evidence for statistically significant excess significance bias was seen for three outcomes (sporadic colorectal adenoma recurrence, Alzheimer's disease, and fractures; supplementary table I).

\section{Significant observational associations without hints of bias}

Of the 48 meta-analyses, 18 (38\%) had nominally statistically significant summary associations according to random effects calculations and had no evidence of small study effects $(\mathrm{P} \geq 0.10)$, not very large heterogeneity $\left(\mathrm{I}^{2} \leq 75 \%\right)$, and no evidence for excess significance (tables $1 \Downarrow$ and $2 \Downarrow$ ). Overall, 12 of these 18 associations were based on cumulative evidence of more than 500 disease events (or more than 5000 total participants if the type of metric was continuous) and also had $\mathrm{P} \leq 0.001$ for the association. These included vitamin $\mathrm{D}$ associations with one cancer (colorectal cancer), five cardiovascular (cardiovascular disease, prevalence of cardiovascular disease, hypertension, ischaemic stroke, and stroke), two cognitive (cognition and depression (cohort studies)), two metabolic (prevalence of metabolic syndrome and type 2 diabetes), one neonatal/infant/child related (small for gestational age), and one pregnancy related outcome (gestational diabetes). Across these 12 associations, the relative risk of the highest versus the lowest category had a median of 0.63 (interquartile range $0.52-0.67$ ).

\section{Meta-analyses of randomised controlled trials of vitamin D supplementation}

We identified 87 meta-analyses of randomised controlled trials of vitamin D supplementation (supplementary table E). Among these, 57 non-overlapping meta-analyses were presented in 19 papers, ${ }^{6} 1107108$ 110-112 114115 118-121 123125127128130131 including 21 $(37 \%)$ in skeletal diseases, seven $(12 \%)$ in metabolic disorders, four $(7 \%)$ in neonatal/infant/child related outcomes, three $(5 \%)$ in cardiovascular diseases, three $(5 \%)$ in pregnancy related outcomes, and $18(32 \%)$ in other outcomes. The median number of studies included was four (range 2-38), and the median number of participants was $446(38-25016)$ (tables $3 \Downarrow$ and $4 \Downarrow)$. Overall, 13 (23\%) of the 57 meta-analyses of randomised controlled trials reported a nominally statistically significant summary result, and these were related to the following outcomes: total cholesterol concentrations, birth weight, head circumference at birth, maternal vitamin D concentrations at term, balance sway, femoral neck bone mineral density, muscle strength, non-vertebral fractures, rate of falls, dental caries in children, parathyroid hormone concentrations in patients with chronic kidney disease (requiring or not requiring dialysis), and risk of hypercalcaemia in patients with chronic kidney disease not requiring dialysis (tables $3 \Downarrow$ and $4 \Downarrow$ ). Figure $4 \Downarrow$ shows a forest plot with the summary effects of all the non-overlapping meta-analyses of randomised controlled trials (for binary outcomes).

We found more than one meta-analysis of randomised controlled trials for 10 outcomes: cardiovascular disease $(n=2$

meta-analyses), diastolic blood pressure $(n=3)$, systolic blood pressure $(n=3)$, birth weight ( $n=3)$, falls $(n=11)$, fractures $(n=5)$, hip fractures $(n=4)$, non-vertebral fractures $(n=2)$, rate of falls $(n=3)$, and mortality $(n=5)$. For half of the outcomes, agreement existed between the meta-analyses on the direction, magnitude, and statistical significance of the effect. Only one of the overlapping meta-analyses reported a statistically significant effect for diastolic blood pressure, birth weight, and non-vertebral fractures. Eleven meta-analyses examined risk of falling, and differences existed in both the magnitude and the statistical significance of the effect but not in the direction of the effect. Finally, three meta-analyses examined rate of falls, and differences existed in the direction, magnitude, and statistical significance of the effect (supplementary table J).

\section{Comparison of findings from observational studies and clinical trials}

One hundred and twenty three (90\%) outcomes were examined only by syntheses of observational evidence $(n=84)$ or only by meta-analyses of randomised evidence $(n=39)$, so we could not compare observational and randomised evidence.

Ten (7\%) outcomes were examined by both meta-analyses of observational studies and meta-analyses of randomised controlled trials: cardiovascular disease, hypertension, birth weight, birth length, head circumference at birth, small for gestational age birth, mortality in patients with chronic kidney 
disease, all cause mortality, fractures, and hip fractures (table $5 \Downarrow$ ). The direction of the association/effect and level of statistical significance was concordant only for birth weight, but this outcome could not be tested for hints of bias in the meta-analysis of observational studies (owing to lack of the individual data). The direction of the association/effect but not the level of statistical significance was concordant in six outcomes (cardiovascular disease, hypertension, birth length, head circumference small for gestational age births, and all cause mortality), but only two of them (cardiovascular disease and hypertension) could be tested and were found to be free from hint of bias and of low heterogeneity in the meta-analyses of observational studies. For mortality in chronic kidney disease patients, fractures in older populations, and hip fractures, both the direction and the level of significance of the association/effect were not concordant.

Finally, four (3\%) outcomes were examined by meta-analyses of randomised controlled trials and systematic reviews of observational studies without a formal meta-analysis (supplementary table B). These included falls, for which systematic reviews concluded that a definite association existed whereas meta-analyses of randomised controlled trials reported a non-statistically significant effect, and length of gestation and bone mineral density in adults and in children, for which the systematic reviews concluded that a suggestive association existed whereas meta-analyses of randomised controlled trials reported a non-statistically significant effect.

\section{Discussion}

Our umbrella review identified 107 systematic literature reviews and 74 meta-analyses of observational studies of plasma vitamin D concentrations and 87 meta-analyses of randomised controlled trials of vitamin D supplementation. The role of vitamin D has been explored in relation to an impressive number of outcomes (137 in total), covering a wide range of diseases, including among others skeletal, malignant, cardiovascular, autoimmune, infectious, and metabolic diseases. We identified a gap in the literature concerning autoimmune disease outcomes, as we found no formal meta-analyses of either observational studies or randomised controlled trials and these were examined only by systematic reviews. Furthermore, cancer, cognitive, and infectious disease outcomes were examined only in observational studies of plasma vitamin D concentrations (either systematic reviews or formal meta-analyses), and we found no meta-analyses of randomised controlled trials of vitamin D supplementation. Comparisons of syntheses of observational versus randomised evidence were possible for only 14 of the 137 outcomes. Largely, this unevenness in observational versus randomised evidence may reflect the low frequency of many of these outcomes, which would be difficult to study conclusively with randomised trials.

Most of the associations that give signals of nominal significance for diverse outcomes are subject to the caveats that generally accompany evidence from observational studies: many of them may be false positives, and very few, if any, may translate to effective interventions when tested in randomised trials. Even meta-analyses of randomised trials may not be conclusive, especially when based on limited sample size and weak levels of statistical significance. On the basis of the results of this umbrella review (table $6 \Downarrow$ ), highly convincing evidence of a clear role of vitamin D with highly significant results in both randomised and observational evidence does not exist for any outcome. Vitamin D supplementation is probably linked to a decrease in dental caries in children and in parathyroid hormone concentrations in patients with chronic kidney disease requiring dialysis and to an increase in maternal vitamin D concentrations at term and in birth weight. Suggestive evidence exists for a correlation between high vitamin D concentrations and low risk of colorectal cancer, non-vertebral fractures, cardiovascular disease, prevalence of cardiovascular disease, hypertension, ischaemic stroke, stroke, cognition, depression, high body mass index, prevalence of metabolic syndrome, type 2 diabetes, head circumference at birth, small for gestational age birth, and gestational diabetes mellitus; reduced levels of balance sway, alkaline phosphatase concentrations in chronic kidney disease patients requiring dialysis, and parathyroid hormone concentrations in chronic kidney disease patients not requiring dialysis; and increased levels of low density lipoprotein, bone mineral density in femoral neck, and muscle strength. On the other hand, suggestive evidence exists that high vitamin D concentrations are linked to an increased rate of falls and risk of hypercalcaemia in chronic kidney disease patients not requiring dialysis.

Most (30/48) of the meta-analyses of observational studies reported a nominally statistically significant result. However, meta-analyses of randomised controlled trials reported a nominally statistically significant summary result for only 13 of the 57 outcomes, and the confidence intervals of the estimates were generally wider than the confidence intervals of the meta-analyses of observational studies. This may reflect lower power in meta-analyses of randomised controlled trials (due to fewer included studies and participants) and a different range of examined outcomes, or it may in part be due to the more conservative results in randomised controlled trials than in observational studies. The highly promising results identified from most of the meta-analyses of observational studies were either not tested or not replicated in meta-analyses of randomised controlled trials. In most cases, this was not only a matter of statistical significance but in addition the meta-analysis effect estimates were close to null for the randomised controlled trials. Genuine differences between these two designs might be due to confounding or biases that operate in observational studies. Alternatively, difficulties in relation to randomised controlled trials of vitamin D supplementation may affect reliability of findings. "Typical" difficulties concern disentangling the effects of multiple compounds when administered simultaneously and assuring an appropriate follow-up period: although this would have been assured for primary outcomes, the follow-up time may be inadequate to allow differences in disease occurrence to become apparent for secondary outcomes. Similarly, an inappropriately low dose or short duration of vitamin D supplementation in the randomised controlled trials might be inadequate to raise the body's vitamin D concentrations enough to show a difference between the arms of a trial. Differences in vitamin D concentrations achieved following supplementation can be much smaller than naturally occurring variation in the general population. ${ }^{132}$ Moreover, large differences in baseline plasma concentrations of 25-hydroxyvitamin D in different populations could interfere with the effect of the supplementation. Finally, contamination with private use of vitamin D might also further dilute any definite associations. ${ }^{133}$

\section{Strengths and weaknesses of study and in relation to other studies}

This umbrella review provides a comprehensive summary of the published literature in relation to the role of vitamin $\mathrm{D}$ in human diseases and health related traits. Beyond summarising the findings for a wide range of outcomes, we explored the extent of bias and heterogeneity in the observational vitamin D 
literature. As in all literature reviews, the quality is directly related to the quality of the included studies. Furthermore, some health related outcomes were poorly covered, and we have flagged this gap. Exploring the relation between vitamin D supplementation dose and effect size reported in randomised controlled trials was beyond the scope of this review. Similarly, we could not evaluate the effect of the different choices of comparison groups (for example, thirds, quarters, fifths) or of varying vitamin D distributions and median differences of the component observational studies.

We decided to exclude observational meta-analyses of vitamin D supplementation and include only meta-analyses of randomised controlled trials in relation to vitamin D supplementation. Meta-analyses of randomised controlled trials are subject to considerably less bias than are those of observational studies and are therefore selected as the standard against which observational meta-analyses of vitamin D concentrations are compared. Meta-analyses of observational studies of supplement intake are unlikely to be more reliable than the meta-analyses of observational studies of associations with vitamin D concentrations, so one could not really use them as a gold standard for assessing how the bias, size, or heterogeneity mapping performs.

We did not identify prominent bias in the observational plasma vitamin D literature, with respect to either the excess significance test (which evaluates whether the results of single studies are over-optimistic compared with the results of the largest study) or the small study effects test (which evaluates whether small studies are consistently more positive or negative than larger studies). This differs from findings of other empirical evaluations of biomarker studies. ${ }^{23-25}$ This is because large studies in our review had relatively similar results to other studies and to the summary meta-analysis effect. This might mean that the same confounding or other biases affected all studies regardless of sample size. Other types of confounding or biases, such as reverse causality, might operate in this field, and these tests are not designed to probe this.

As we were preparing our review for submission, a relevant overview of observational studies and randomised controlled trials of vitamin D status or supplementation and ill health was published online. ${ }^{132}$ Eligible papers included prospective cohort studies and randomised controlled trials on chronic diseases (excluding skeletal diseases) in adults and were identified through a search in PubMed and Embase from inception to 31 December 2012. The authors identified 82 prospective cohort studies, 84 randomised controlled trials, 20 meta-analyses of 208 prospective studies, and eight meta-analyses of 88 randomised controlled trials. Similarly to our findings, this overview identified a discrepancy between findings of observational studies and of randomised controlled trials, with most supplementation trials not showing an effect of vitamin $\mathrm{D}$ on disease occurrence, and the authors concluded that low vitamin D status is more likely to be a marker of ill health than a cause of disease. The results of this overview were similar to ours, but our review is more comprehensive in terms of the number and range of outcomes covered and different regarding the included studies (we included systematic reviews and meta-analyses rather than original studies), the underlying population (we did not restrict our analysis to adults or particular clinical settings), and the statistical analyses performed (including bias tests).

\section{Possible explanations and implications for clinicians and policy makers}

No universal consensus exists on the optimal vitamin D intake or the optimal plasma concentrations of 25-hydroxyvitamin D. The Institute of Medicine issued a report in 2011 stating that 25 -hydroxyvitamin $\mathrm{D}$ concentrations of $50 \mathrm{nmol} / \mathrm{L}$ are adequate and suggested that these concentrations can be achieved by 600 IU of vitamin D per day. ${ }^{20}$ Furthermore, vitamin D supplementation has been long thought to protect against osteoporosis and consequently to reduce the risk and number of fractures, so large numbers of older adults use vitamin D supplements. ${ }^{134}$ That nearly half of the meta-analyses of randomised controlled trials were related to skeletal diseases is not surprising. Several randomised controlled trials have identified a protective effect of vitamin D supplementation (with or without co-administration of calcium) against fractures, ${ }^{135} 136$ but trials that examined vitamin D only supplementation failed to replicate these findings. ${ }^{107}$ Similarly, a very recent meta-analysis of randomised controlled trials on bone mineral density failed to show a definite association and concluded that widespread use of vitamin D supplementation for prevention of osteoporosis is not supported by the evidence, ${ }^{131} \mathrm{a}$ fact that is also verified by the findings of our review. Vitamin D might not be as essential as previously thought in maintaining bone mineral density. Similar are our findings for falls, with the results of two recent Cochrane reviews failing to find a protective effect of vitamin D only supplementation on the risk or rate of falling in older adults (both in care facilities or hospitals and in the community). ${ }^{111} 115$

The lack of convincing associations and the relative dearth of probable associations (table $6 \Downarrow$ ) suggest that evidence for benefits that may be reaped from population-wide vitamin $\mathrm{D}$ supplementation is weak. Probable associations, where highly significant effects appear in randomised trials, hold the most promise for clinical translation, but they pertain to specific populations (children, pregnant women, patients with chronic kidney disease), and even in these cases the evidence is not sufficient to make universal recommendations about daily intake. Optimal vitamin D intake/concentration may not be the same for all outcomes. ${ }^{137}$ In addition, the absorption/metabolism of vitamin D differs among individuals; in practice, this means that the same supplementation dose is not going to have a stable effect on plasma vitamin D concentration, introducing yet another source of variability. Moreover, individual characteristics (such as body mass index or disease) will further modify final concentrations in circulation. In this regard, current recommendations on daily supplementation of vitamin D are largely expert driven, rather than evidence based, ${ }^{20}$ and this may be the reason why they have generated so much debate. Some recommendations that focus on specific outcomes such as prevention of falls and fractures and in which even higher doses of vitamin D are recommended (for example, the American Endocrine Society, ${ }^{138}$ Osteoporosis Canada ${ }^{139}$ ) seem actually to be contradicted by the evidence, which shows no consistent beneficial effects in randomised trials. Our overview of the evidence on vitamin D suggests that strong recommendations cannot be made regarding its supplementation.

\section{Conclusions, unanswered questions, and future research}

In conclusion, although vitamin $\mathrm{D}$ has been extensively studied in relation to a range of outcomes and some indications exist that low plasma vitamin D concentrations might be linked to several diseases, firm universal conclusions about its benefits cannot be drawn. Observational studies have identified links 
with several diseases, but these have either not been evaluated or not been replicated in randomised controlled trials.

Randomised controlled trials for autoimmune and cancer related outcomes are clearly lacking. In addition, earlier evidence from randomised controlled trials that vitamin D supplementation (with or without calcium) increases bone mineral density and reduces the risk of fractures in older people is not seen in clinical trials that examine vitamin D only supplementation. On the basis of the results of this review, an association between vitamin D concentrations and birth weight, dental caries in children, maternal vitamin D concentrations at term, and parathyroid hormone concentrations in patients with chronic kidney disease requiring dialysis is probable, but further studies and better designed trials are needed to draw firmer conclusions.

Contributors: ET, IT, and JPAI conceived the study. ET and IT did the systematic reviews. ET, IT, and LZ did the data abstraction. ET did the statistical analysis. All authors contributed to writing and reviewing the manuscript. ET and JPAI are the guarantors.

Funding: No specific funding.

Competing interests: All authors have completed the ICMJE uniform disclosure form at www.icmje.org/coi_disclosure.pdf (available on request from the corresponding author) and declare: no support from any organisation for the submitted work; no financial relationships with any organisations that might have an interest in the submitted work in the previous three years; no other relationships or activities that could appear to have influenced the submitted work.

Ethical approval: Not needed.

Data sharing: No additional data available.

Transparency declaration: The lead authors (the manuscript's guarantors) affirm that the manuscript is an honest, accurate, and transparent account of the study being reported; that no important aspects of the study have been omitted; and that any discrepancies from the study as planned have been explained.

Lips P. Vitamin D physiology. Prog Biophys Mol Biol 2006;92:4-8.

2 Holick MF. McCollum Award Lecture, 1994: vitamin D-new horizons for the 21st century. Am J Clin Nutr 1994;60:619-30.

3 Tang BM, Eslick GD, Nowson C, Smith C, Bensoussan A. Use of calcium or calcium in combination with vitamin $\mathrm{D}$ supplementation to prevent fractures and bone loss in people aged 50 years and older: a meta-analysis. Lancet 2007;370:657-66.

4 Bischoff-Ferrari HA, Dawson-Hughes B, Baron JA, Burckhardt P, Li R, Spiegelman D, et al. Calcium intake and hip fracture risk in men and women: a meta-analysis of prospective cohort studies and randomized controlled trials. Am J Clin Nutr 2007;86:1780-90.

5 Bischoff-Ferrari HA, Willett WC, Wong JB, Stuck AE, Staehelin HB, Orav EJ, et al. Prevention of nonvertebral fractures with oral vitamin $D$ and dose dependency: a meta-analysis of randomized controlled trials. Arch Intern Med 2009;169:551-61.

6 Visser M, Deeg DJ, Lips P. Low vitamin D and high parathyroid hormone levels as determinants of loss of muscle strength and muscle mass (sarcopenia): the Longitudinal Aging Study Amsterdam. J Clin Endocrinol Metab 2003;88:5766-72.

7 Bischoff-Ferrari HA, Dawson-Hughes B, Staehelin HB, Orav JE, Stuck AE, Theiler R, et al. Fall prevention with supplemental and active forms of vitamin D: a meta-analysis of randomised controlled trials. BMJ 2009;339:b3692.

8 Lappe JM, Travers-Gustafson D, Davies KM, Recker RR, Heaney RP. Vitamin D and calcium supplementation reduces cancer risk: results of a randomized trial. Am J Clin Nutr 2007;85:1586-91

9 Giovannucci E, Liu Y, Hollis BW, Rimm EB. 25-hydroxyvitamin D and risk of myocardial infarction in men: a prospective study. Arch Intern Med 2008;168:1174-80.

10 Wang TJ, Pencina MJ, Booth SL, Jacques PF, Ingelsson E, Lanier K, et al. Vitamin D deficiency and risk of cardiovascular disease. Circulation 2008;117:503-11.

11 Pittas AG, Lau J, Hu FB, Dawson-Hughes B. The role of vitamin D and calcium in type 2 diabetes: a systematic review and meta-analysis. J Clin Endocrinol Metab 2007;92:2017-29.

12 Yamshchikov AV, Desai NS, Blumberg HM, Ziegler TR, Tangpricha V. Vitamin D for treatment and prevention of infectious diseases: a systematic review of randomized controlled trials. Endocr Pract 2009;15:438-49.

13 Cutolo M, Otsa K, Uprus M, Paolino S, Seriolo B. Vitamin D in rheumatoid arthritis. Autoimmun Rev 2007;7:59-64.

14 Merlino LA, Curtis J, Mikuls TR, Cerhan JR, Criswell LA, Saag KG. Vitamin D intake is inversely associated with rheumatoid arthritis: results from the lowa Women's Health Study. Arthritis Rheum 2004;50:72-7.

15 Myhr KM. Vitamin D treatment in multiple sclerosis. J Neurol Sci 2009;286:104-8.

16 Melamed ML, Michos ED, Post W, Astor B. 25-hydroxyvitamin D levels and the risk of mortality in the general population. Arch Intern Med 2008;168:1629-37.

17 Zgaga L, Theodoratou E, Farrington SM, Agakov F, Tenesa A, Walker M, et al. Diet, environmental factors, and lifestyle underlie the high prevalence of vitamin $D$ deficiency in healthy adults in Scotland, and supplementation reduces the proportion that are severely deficient. J Nutr 2011;141:1535-42.
18 Holick MF. Vitamin D deficiency. N Engl J Med 2007;357:266-81.

9 Maxmen A. Nutrition advice: the vitamin D-lemma. Nature 2011:475:23-5.

20 Ross AC, Manson JE, Abrams SA, Aloia JF, Brannon PM, Clinton SK, et al. The 2011 report on dietary reference intakes for calcium and vitamin $D$ from the Institute of Medicine: what clinicians need to know. J Clin Endocrinol Metab 2011;96:53-8.

21 Ioannidis JP. Integration of evidence from multiple meta-analyses: a primer on umbrella reviews, treatment networks and multiple treatments meta-analyses. CMAJ 2009:181:488-93.

22 Ioannidis JP, Patsopoulos NA, Rothstein HR. Reasons or excuses for avoiding meta-analysis in forest plots. BMJ 2008;336:1413-5.

23 Tzoulaki I, Siontis KC, Evangelou E, loannidis JP. Bias in associations of emerging biomarkers with cardiovascular disease. JAMA Intern Med 2013;173:664-71.

24 Tsilidis KK, Papatheodorou SI, Evangelou E, Ioannidis JP. Evaluation of excess statistical significance in meta-analyses of 98 biomarker associations with cancer risk. $\mathrm{J}$ Natl Cancer Inst 2012;104:1867-78.

25 Tsilidis KK, Panagiotou OA, Sena ES, Aretouli E, Evangelou E, Howells DW, et al. Evaluation of excess significance bias in animal studies of neurological diseases. PLOS Biol 2013;11:e1001609.

26 Lau J, loannidis JP, Schmid CH. Quantitative synthesis in systematic reviews. Ann Intern Med 1997;127:820-6.

27 Ioannidis JP, Patsopoulos NA, Evangelou E. Uncertainty in heterogeneity estimates in meta-analyses. BMJ 2007;335:914-6.

28 Egger M, Davey Smith G, Schneider M, Minder C. Bias in meta-analysis detected by a simple, graphical test. BMJ 1997;315:629-34

29 Ioannidis JP. Excess significance bias in the literature on brain volume abnormalities. Arch Gen Psychiatry 2011;68:773-80.

30 Kavvoura FK, McQueen MB, Khoury MJ, Tanzi RE, Bertram L, Ioannidis JP. Evaluation of the potential excess of statistically significant findings in published genetic association studies: application to Alzheimer's disease. Am J Epidemiol 2008;168:855-65.

31 loannidis JP, Trikalinos TA. An exploratory test for an excess of significant findings. Clin Trials 2007:4:245-53.

32 Ioannidis JP. Clarifications on the application and interpretation of the test for excess significance and its extensions. J Math Psychol 2013;57:184-7.

33 Freedman LS. Tables of the number of patients required in clinical trials using the logrank test. Stat Med 1982;1:121-9.

34 Chinn S. A simple method for converting an odds ratio to effect size for use in meta-analysis. Stat Med 2000;19:3127-31.

35 Lee JE, Li H, Chan AT, Hollis BW, Lee IM, Stampfer MJ, et al. Circulating levels of vitamin D and colon and rectal cancer: the Physicians' Health Study and a meta-analysis of prospective studies. Cancer Prev Res (Phila Pa) 2011;4:735-43.

36 Aghajafari F, Nagulesapillai T, Ronksley PE, Tough SC, O'Beirne M, Rabi DM. Association between maternal serum 25-hydroxyvitamin $D$ level and pregnancy and neonatal outcomes: systematic review and meta-analysis of observational studies. BMJ 2013;346:f1169.

37 Lai JK, Lucas RM, Clements MS, Roddam AW, Banks E. Hip fracture risk in relation to vitamin $D$ supplementation and serum 25-hydroxyvitamin $D$ levels: a systematic review and meta-analysis of randomised controlled trials and observational studies. BMC Public Health 2010;10:331.

38 Saneei P, Salehi-Abargouei A, Esmaillzadeh A. Serum 25-hydroxy vitamin D levels in relation to body mass index: a systematic review and meta-analysis. Obes Rev 2013;14:393-404.

39 Sterne JA, Davey Smith G. Sifting the evidence-what's wrong with significance tests? BMJ 2001;322:226-31.

40 Ioannidis JP, Tarone R, McLaughlin JK. The false-positive to false-negative ratio in epidemiologic studies. Epidemiology 2011;22:450-6.

41 Johnson VE. Revised standards for statistical evidence. Proc Natl Acad Sci U S A 2013;110:19313-7.

42 Annweiler C, Allali G, Allain P, Bridenbaugh S, Schott AM, Kressig RW, et al. Vitamin D and cognitive performance in adults: a systematic review. Eur J Neurol 2009:16:1083-9.

43 Barnard K, Colon-Emeric C. Extraskeletal effects of vitamin $D$ in older adults: cardiovascular disease, mortality, mood, and cognition. Am J Geriatr Pharmacother 2010;8:4-33.

44 Buttigliero C, Monagheddu C, Petroni P, Saini A, Dogliotti L, Ciccone G, et al. Prognostic role of vitamin $\mathrm{D}$ status and efficacy of vitamin $\mathrm{D}$ supplementation in cancer patients: a systematic review. Oncologist 2011:16:1215-27.

45 Christesen HT, Elvander C, Lamont RF, Jorgensen JS. The impact of vitamin D in pregnancy on extraskeletal health in children: a systematic review. Acta Obstet Gyneco Scand 2012;91:1368-80.

46 Christesen HT, Falkenberg T, Lamont RF, Jorgensen JS. The impact of vitamin D on pregnancy: a systematic review. Acta Obstet Gynecol Scand 2012:91:1357-67.

47 Chung M, Balk EM, Brendel M, Ip S, Lau J, Lee J, et al. Vitamin D and calcium: a systematic review of health outcomes. Evid Rep Technol Assess (Full Rep) 2009;(183):1-420.

48 Cranney A, Horsley T, O'Donnell S, Weiler H, Puil L, Ooi D, et al. Effectiveness and safety of vitamin D in relation to bone health. Evid Rep Technol Assess (Full Rep) 2007;(158):1-235.

49 Kriegel MA, Manson JE, Costenbader KH. Does vitamin D affect risk of developing autoimmune disease? A systematic review. Semin Arthritis Rheum 2011;40:512-31.e8.

50 Nassar N, Halligan GH, Roberts CL, Morris JM, Ashton AW. Systematic review of first-trimester vitamin D normative levels and outcomes of pregnancy. Am J Obstet Gynecol 2011;205:208.e1-7.

51 Pilz S, Tomaschitz A, Ritz E, Pieber TR. Vitamin D status and arterial hypertension: a systematic review. Nat Rev Cardiol 2009;6:621-30.

52 Pittas AG, Chung M, Trikalinos T, Mitri J, Brendel M, Patel K, et al. Systematic review: vitamin D and cardiometabolic outcomes. Ann Intern Med 2010;152:307-14.

53 Renzaho AM, Halliday JA, Nowson C. Vitamin D, obesity, and obesity-related chronic disease among ethnic minorities: a systematic review. Nutrition 2011;27:868-79.

54 Van der Rhee H, Coebergh JW, de Vries E. Sunlight, vitamin D and the prevention of cancer: a systematic review of epidemiological studies. Eur J Cancer Prev 2009:18:458-75.

55 Yaghjyan L, Colditz GA, Drake B. Vitamin D and mammographic breast density: a systematic review. Cancer Causes Control 2012;23:1-13.

56 Antico A, Tampoia M, Tozzoli R, Bizzaro N. Can supplementation with vitamin D reduce the risk or modify the course of autoimmune diseases? A systematic review of the literature. Autoimmun Rev 2012;12:127-36.

57 Cook LS, Neilson HK, Lorenzetti DL, Lee RC. A systematic literature review of vitamin D and ovarian cancer. Am J Obstet Gynecol 2010;203:70.e1-8. 


\section{What is already known on this topic}

The role of vitamin $\mathrm{D}$ has been explored both in a large number of observational studies and randomised controlled trials and in relation to a multitude of health outcomes

The composite literature is often confusing and has led to heated debates about the role of vitamin $\mathrm{D}$, the optimal concentrations, and related guidelines for supplementation

Recent reports have highlighted the lack of concordance between observational studies and randomised controlled trials, concluding that vitamin $\mathrm{D}$ is more likely to be a correlate marker of overall health and not causally involved in disease

\section{What this study adds}

This umbrella review collectively presents the evidence from systematic reviews and meta-analyses of observational studies and randomised controlled trials in relation to 137 different outcomes covering a wide range of diseases

An association between vitamin $\mathrm{D}$ concentrations and birth weight, dental caries in children, maternal vitamin $\mathrm{D}$ concentrations at term and parathyroid hormone concentrations in chronic kidney disease patients requiring dialysis is probable

In contrast to previous reports, the findings cast doubt on the effectiveness of vitamin D only supplementation for prevention of osteoporosis or falls

This review highlights the absence of meta-analyses in relation to autoimmune disease and the absence of meta-analyses of randomised clinical trials of vitamin D supplementation in respect of cancer, cognitive, and infectious disease outcomes

58 Kelly JL, Friedberg JW, Calvi LM, Van Wijngaarden E, Fisher SG. Vitamin D and non-Hodgkin lymphoma risk in adults: a review. Cancer Invest 2009;27:942-51.

59 Sakthiswary R, Raymond AA. The clinical significance of vitamin D in systemic lupus erythematosus: a systematic review. PLoS One 2013;8(1).

60 Song GG, Bae SC, Lee YH. Association between vitamin D intake and the risk of rheumatoid arthritis: a meta-analysis. Clin Rheumatol 2012;31:1733-9.

61 Thorne-Lyman A, Fawzi WW. Vitamin D during pregnancy and maternal, neonatal and infant health outcomes: a systematic review and meta-analysis. Paediatr Perinat Epidemiol 2012;26(suppl 1):75-90.

62 Dolinsky DH, Armstrong S, Mangarelli C, Kemper AR. The association between vitamin $\mathrm{D}$ and cardiometabolic risk factors in children: a systematic review. Clin Pediatr (Phila) 2013:52:210-23.

63 Jolliffe DA, Griffiths CJ, Martineau AR. Vitamin D in the prevention of acute respiratory infection: systematic review of clinical studies. J Steroid Biochem Mol Biol 2013;136:321-9.

64 Cao Y, Winzenberg T, Nguo K, Lin J, Jones G, Ding C. Association between serum levels of 25-hydroxyvitamin $\mathrm{D}$ and osteoarthritis: a systematic review. Rheumatology 2013;52:1323-34

65 Balion C, Griffith LE, Strifler L, Henderson M, Patterson C, Heckman G, et al. Vitamin D, cognition, and dementia: a systematic review and meta-analysis. Neurology 2012;79:1397-405

66 Brondum-Jacobsen P, Benn M, Jensen GB, Nordestgaard BG. 25-hydroxyvitamin D levels and risk of ischemic heart disease, myocardial infarction, and early death: population-based study and meta-analyses of 18 and 17 studies. Arterioscler Thromb Vasc Biol 2012:32:2794-802.

67 Burgaz A, Orsini N, Larsson SC, Wolk A. Blood 25-hydroxyvitamin D concentration and hypertension: a meta-analysis. J Hypertens 2011;29:636-45.

68 Chen P, Hu P, Xie D, Qin Y, Wang F, Wang H. Meta-analysis of vitamin D, calcium and the prevention of breast cancer. Breast Cancer Res Treat 2010;121:469-77.

69 Chowdhury R, Stevens S, Ward H, Chowdhury S, Sajiad A, Franco OH. Circulating vitamin $D$, calcium and risk of cerebrovascular disease: a systematic review and meta-analysis. Eur J Epidemiol 2012;27:581-91.

70 Chung M, Lee J, Terasawa T, Lau J, Trikalinos TA. Vitamin D with or without calcium supplementation for prevention of cancer and fractures: an updated meta-analysis for the U.S. Preventive Services Task Force. Ann Intern Med 2011;155:827-38.

71 Etgen T, Sander D, Bickel H, Sander K, Forstl H. Vitamin D deficiency, cognitive impairment and dementia: a systematic review and meta-analysis. Dement Geriatr Cogn Disord 2012;33:297-305

72 Fedirko V, Bostick RM, Goodman M, Flanders WD, Gross MD. Blood 25-hydroxyvitamin D3 concentrations and incident sporadic colorectal adenoma risk: a pooled case-control study. Am J Epidemiol 2010;172:489-500.

73 Forouhi NG, Ye Z, Rickard AP, Khaw KT, Luben R, Langenberg C, et al. Circulating 25-hydroxyvitamin $D$ concentration and the risk of type 2 diabetes: results from the European Prospective Investigation into Cancer (EPIC)-Norfolk cohort and updated meta-analysis of prospective studies. Diabetologia 2012;55:2173-82.

74 Gallicchio L, Moore LE, Stevens VL, Ahn J, Albanes D, Hartmuller V, et al. Circulating 25-hydroxyvitamin D and risk of kidney cancer: Cohort Consortium Vitamin D Pooling Project of Rarer Cancers. Am J Epidemiol 2010;172:47-57.

75 Gandini S, Boniol M, Haukka J, Byrnes G, Cox B, Sneyd MJ, et al. Meta-analysis of observational studies of serum 25-hydroxyvitamin $\mathrm{D}$ levels and colorectal, breast and prostate cancer and colorectal adenoma. Int J Cancer 2011;128:1414-24.

76 Gilbert R, Martin RM, Beynon R, Harris R, Savovic J, Zuccolo L, et al. Associations of circulating and dietary vitamin $\mathrm{D}$ with prostate cancer risk: a systematic review and dose-response meta-analysis. Cancer Causes Control 2011;22:319-40.

77 Gorham ED, Garland CF, Garland FC, Grant WB, Mohr SB, Lipkin M, et al. Optimal vitamin D status for colorectal cancer prevention: a quantitative meta analysis. Am J Prev Med 2007;32:210-6.

78 Grandi NC, Breitling LP, Brenner H. Vitamin D and cardiovascular disease: systematic review and meta-analysis of prospective studies. Prev Med 2010;51:228-33.

79 Ma Y, Zhang P, Wang F, Yang J, Liu Z, Qin H. Association between vitamin D and risk of colorectal cancer: a systematic review of prospective studies. $J$ Clin Oncol 2011;29:3775-82

80 Mitri J, Muraru MD, Pittas AG. Vitamin D and type 2 diabetes: a systematic review. Eur $J$ Clin Nutr 2011;65:1005-15.

81 Mohr SB, Gorham ED, Alcaraz JE, Kane CJ, Macera CA, Parsons JK, et al. Serum 25-hydroxyvitamin $\mathrm{D}$ and prevention of breast cancer: pooled analysis [correction in: Anticancer Res 2011:31:3637]. Anticancer Res 2011:31:2939-48.

82 Nnoaham KE, Clarke A. Low serum vitamin D levels and tuberculosis: a systematic review and meta-analysis. Int J Epidemiol 2008;37:113-9.
83 Parker J, Hashmi O, Dutton D, Mavrodaris A, Stranges S, Kandala N-B, et al. Levels of vitamin $\mathrm{D}$ and cardiometabolic disorders: systematic review and meta-analysis. Maturitas 2010;65:225-36.

84 Pilz S, lodice S, Zittermann A, Grant WB, Gandini S. Vitamin D status and mortality risk in CKD: a meta-analysis of prospective studies. Am J Kidney Dis 2011;58:374-82.

85 Poel YH, Hummel P, Lips P, Stam F, van der Ploeg T, Simsek S. Vitamin D and gestational diabetes: a systematic review and meta-analysis. Eur J Intern Med 2012;23:465-9.

86 Purdue MP, Freedman DM, Gapstur SM, Helzlsouer KJ, Laden F, Lim U, et al. Circulating 25-hydroxyvitamin D and risk of non-hodgkin lymphoma: Cohort Consortium Vitamin D Pooling Project of Rarer Cancers. Am J Epidemiol 2010;172:58-69.

87 Sokol SI, Tsang P, Aggarwal V, Melamed ML, Srinivas VS. Vitamin D status and risk of cardiovascular events: lessons learned via systematic review and meta-analysis. Cardiol Rev 2011;19:192-201.

88 Stolzenberg-Solomon RZ, Jacobs EJ, Arslan AA, Qi D, Patel AV, Helzlsouer KJ, et al. Circulating 25-hydroxyvitamin $D$ and risk of pancreatic cancer: Cohort Consortium Vitamin D Pooling Project of Rarer Cancers. Am J Epidemiol 2010;172:81-93.

89 Sun Q, Pan A, Hu FB, Manson JE, Rexrode KM. 25-hydroxyvitamin D levels and the risk of stroke: a prospective study and meta-analysis. Stroke 2012;43:1470-7.

90 Touvier M, Chan DS, Lau R, Aune D, Vieira R, Greenwood DC, et al. Meta-analyses of vitamin $D$ intake, 25-hydroxyvitamin $D$ status, vitamin $D$ receptor polymorphisms, and colorectal cancer risk. Cancer Epidemiol Biomarkers Prev 2011;20:1003-16.

91 Weatherall M. A meta-analysis of 25 hydroxyvitamin $\mathrm{D}$ in older people with fracture of the proximal femur. NZ Med J 2000:113:137-40.

92 Wei MY, Garland CF, Gorham ED, Mohr SB, Giovannucci E. Vitamin D and prevention of colorectal adenoma: a meta-analysis. Cancer Epidemiol Biomarkers Prev 2008;17:2958-69.

93 Yin L, Grandi N, Raum E, Haug U, Arndt V, Brenner H. Meta-analysis: Iongitudinal studies of serum vitamin D and colorectal cancer risk. Aliment Pharmacol Ther 2009;30:113-25.

94 Yin L, Grandi N, Raum E, Haug U, Arndt V, Brenner H. Meta-analysis: serum vitamin D and breast cancer risk. Eur $J$ Cancer 2010;46:2196-205.

95 Yin L, Grandi N, Raum E, Haug U, Arndt V, Brenner H. Meta-analysis: serum vitamin D and colorectal adenoma risk. Prev Med 2011;53:10-6

96 Yin L, Grandi N, Raum E, Haug U, Arndt V, Brenner H. Meta-analysis: circulating vitamin D and ovarian cancer risk. Gynecol Oncol 2011;121:369-75.

97 Yin L, Raum E, Haug U, Arndt V, Brenner H. Meta-analysis of longitudinal studies: serum vitamin D and prostate cancer risk. Cancer Epidemiol 2009:33:435-45.

98 Anglin RE, Samaan Z, Walter SD, Sarah DM. Vitamin D deficiency and depression in adults: systematic review and meta-analysis. Br J Psychiatry 2013;202:100-7.

99 Annweiler C, Llewellyn DJ, Beauchet O. Low serum vitamin D concentrations in Alzheimer's disease: a systematic review and meta-analysis. J Alzheimers Dis 2013;33:659-74.

100 Brondum-Jacobsen P, Nordestgaard Bo G, Schnohr P, Benn M. 25-hydroxyvitamin D and symptomatic ischemic stroke: an original study and meta-analysis. Ann Neurol 2013;73:38-47.

101 Chen P, Li M, Gu X, Liu Y, Li X, Li C, et al. Higher blood 25(OH)D level may reduce the breast cancer risk: evidence from a Chinese population based case-control study and meta-analysis of the observational studies. PLoS One 2013;8(1).

102 Wang L, Song Y, Manson JE, Pilz S, Marz W, Michaelsson K, et al. Circulating 25-hydroxy-vitamin $D$ and risk of cardiovascular disease: a meta-analysis of prospective studies. Circ Cardiovasc Qual Outcomes 2012;5:819-29.

103 Afzal S, Bojesen SE, Nordestgaard BG. Low 25-hydroxyvitamin D and risk of type 2 diabetes: a prospective cohort study and metaanalysis. Clin Chem 2013;59:381-91.

104 Kunutsor SK, Apekey TA, Steur M. Vitamin D and risk of future hypertension: meta-analysis of 283,537 participants. Eur J Epidemiol 2013;28:205-21.

105 Bauer SR, Hankinson SE, Bertone-Johnson ER, Ding EL. Plasma vitamin D levels, menopause, and risk of breast cancer: dose-response meta-analysis of prospective studies. Medicine (Baltimore) 2013;92:123-31.

106 Autier P, Gandini S. Vitamin D supplementation and total mortality: a meta-analysis of randomized controlled trials. Arch Intern Med 2007;167:1730-7.

107 Avenell A, Gillespie WJ, Gillespie LD, O'Connell D. Vitamin D and vitamin D analogues for preventing fractures associated with involutional and post-menopausal osteoporosis. Cochrane Database Syst Rev 2009;(2):CD000227

108 Bergman GJ, Fan T, McFetridge JT, Sen SS. Efficacy of vitamin D3 supplementation in preventing fractures in elderly women: a meta-analysis. Curr Med Res Opin 2010;26:1193-201

109 Bischoff-Ferrari HA, Dawson-Hughes B, Willett WC, Staehelin HB, Bazemore MG, Zee RY, et al. Effect of vitamin D on falls: a meta-analysis. JAMA 2004:291:1999-2006.

110 Bjelakovic G, Gluud LL, Nikolova D, Whitfield K, Wetterslev J, Simonetti RG, et al. Vitamin D supplementation for prevention of mortality in adults. Cochrane Database Syst Rev 2011;(7):CD007470. 
111 Cameron ID, Gillespie LD, Robertson MC, Murray GR, Hill KD, Cumming RG, et al. Interventions for preventing falls in older people in care facilities and hospitals. Cochrane Database Syst Rev 2012;(12):CD005465.

112 De-Regil LM, Palacios C, Ansary A, Kulier R, Pena-Rosas JP. Vitamin D supplementation for women during pregnancy. Cochrane Database Syst Rev 2012;(2):CD008873.

113 Elamin MB, Abu Elnour NO, Elamin KB, Fatourechi MM, Alkatib AA, Almandoz JP, et al. Vitamin D and cardiovascular outcomes: a systematic review and meta-analysis. J Clin Endocrinol Metab 2011:96:1931-42.

114 George PS, Pearson ER, Witham MD. Effect of vitamin D supplementation on glycaemic control and insulin resistance: a systematic review and meta-analysis. Diabet Med 2012;29:e142-50.

115 Gillespie LD, Robertson MC, Gillespie WJ, Sherrington C, Gates S, Clemson LM, et al. Interventions for preventing falls in older people living in the community. Cochrane Database Syst Rev 2012;(9):CD007146.

116 DIPART (Vitamin D Individual Patient Analysis of Randomized Trials) Group. Patient level pooled analysis of 68500 patients from seven major vitamin D fracture trials in US and Europe. BMJ 2010;340:b5463.

117 Kalyani RR, Stein B, Valiyil R, Manno R, Maynard JW, Crews DC. Vitamin D treatment for the prevention of falls in older adults: systematic review and meta-analysis. $J$ Am Geriatr Soc 2010:58:1299-310.

118 Muir SW, Montero-Odasso M. Effect of vitamin D supplementation on muscle strength, gait and balance in older adults: a systematic review and meta-analysis. $J$ Am Geriatr Soc 2011;59:2291-300.

119 Murad MH, Elamin KB, Abu Elnour NO, Elamin MB, Alkatib AA, Fatourechi MM, et al. The effect of vitamin D on falls: a systematic review and meta-analysis. $J$ Clin Endocrinol Metab 2011:96:2997-3006.

120 Palmer SC, McGregor DO, Craig JC, Elder G, Macaskill P, Strippoli GF. Vitamin D compounds for people with chronic kidney disease not requiring dialysis. Cochrane Database Syst Rev 2009;(4):CD008175.

121 Palmer SC, McGregor DO, Craig JC, Elder G, Macaskill P, Strippoli GF. Vitamin D compounds for people with chronic kidney disease requiring dialysis. Cochrane Database Syst Rev 2009;(4):CD005633.

122 Rejnmark L, Avenell A, Masud T, Anderson F, Meyer HE, Sanders KM, et al. Vitamin D with calcium reduces mortality: patient level pooled analysis of 70,528 patients from eight major vitamin D trials. J Clin Endocrinol Metab 2012;97:2670-81.

123 Wang H, Xia N, Yang Y, Peng D-Q. Influence of vitamin D supplementation on plasma lipid profiles: a meta-analysis of randomized controlled trials. Lipids Health Dis 2012:11:42.

124 Wang L, Manson JE, Song Y, Sesso HD. Systematic review: vitamin D and calcium supplementation in prevention of cardiovascular events. Ann Intern Med 2010;152:315-23.

125 Winzenberg T, Powell S, Shaw KA, Jones G. Effects of vitamin D supplementation on bone density in healthy children: systematic review and meta-analysis. $B M J$ 2011;342:c7254.

126 Witham MD, Nadir MA, Struthers AD. Effect of vitamin D on blood pressure: a systematic review and meta-analysis. J Hypertens 2009;27:1948-54.

127 Wu SH, Ho SC, Zhong L. Effects of vitamin D supplementation on blood pressure. South Med J 2010;103:729-37.
128 Hujoel PP. Vitamin D and dental caries in controlled clinical trials: systematic review and meta-analysis. Nutr Rev 2013;71:88-97.

129 Kandula P, Dobre M, Schold JD, Schreiber Jr MJ, Mehrotra R, Navaneethan SD. Vitamin $\mathrm{D}$ supplementation in chronic kidney disease: a systematic review and meta-analysis of observational studies and randomized controlled trials. Clin J Am Soc Nephrol 2011;6:50-62.

130 Myung SK, Ju W, Cho B, On SW, Park SM, Koo BK, et al. Efficacy of vitamin and antioxidant supplements in prevention of cardiovascular disease: systematic review and meta-analysis of randomised controlled trials. BMJ 2013;346:f10.

131 Reid IR, Bolland MJ, Grey A. Effects of vitamin D supplements on bone mineral density: a systematic review and meta-analysis. Lancet 2014;383:146-55.

132 Autier P, Boniol M, Pizot C, Mullie P. Vitamin D status and ill health: a systematic review. Lancet Diabetes Endocrinol 2014;2:76-89.

133 Bolland MJ, Grey A, Gamble GD, Reid IR. Calcium and vitamin D supplements and health outcomes: a reanalysis of the Women's Health Initiative (WHI) limited-access data set. Am J Clin Nutr 2011;94:1144-9.

134 Bailey RL, Dodd KW, Goldman JA, Gahche JJ, Dwyer JT, Moshfegh AJ, et al. Estimation of total usual calcium and vitamin D intakes in the United States. J Nutr 2010;140:817-22.

135 Bischoff-Ferrari HA, Willett WC, Wong JB, Giovannucci E, Dietrich T, Dawson-Hughes B. Fracture prevention with vitamin $D$ supplementation: a meta-analysis of randomized controlled trials. JAMA 2005;293:2257-64.

136 Bischoff-Ferrari HA, Willett WC, Orav EJ, Lips P, Meunier PJ, Lyons RA, et al. A pooled analysis of vitamin $D$ dose requirements for fracture prevention [correction in $N$ Engl $J$ Med 2012;367:481]. N Engl J Med 2012;367:40-9.

137 Spedding S, Vanlint S, Morris H, Scragg R. Does vitamin D sufficiency equate to a single serum 25 -hydroxyvitamin $\mathrm{D}$ level or are different levels required for non-skeletal diseases? Nutrients 2013:5:5127-39.

138 Holick MF, Binkley NC, Bischoff-Ferrari HA, Gordon CM, Hanley DA, Heaney RP, et al. Evaluation, treatment, and prevention of vitamin $D$ deficiency: an Endocrine Society clinical practice guideline. J Clin Endocrinol Metab 2011;96:1911-30.

139 Hanley DA, Cranney A, Jones G, Whiting SJ, Leslie WD, Cole DE, et al. Vitamin D in adult health and disease: a review and guideline statement from Osteoporosis Canada. CMAJ 2010;182:E610-8.

140 Altman DG, Bland JM. How to obtain the P value from a confidence interval. BMJ 2011;343:d2304

\section{Accepted: 24 February 2014}

\section{Cite this as: BMJ 2014;348:g2035}

This is an Open Access article distributed in accordance with the Creative Commons Attribution Non Commercial (CC BY-NC 3.0) license, which permits others to distribute, remix, adapt, build upon this work non-commercially, and license their derivative works on different terms, provided the original work is properly cited and the use is non-commercial. See: http://creativecommons.org/licenses/by-nc/3.0/. 


\section{Tables}

Table 1 Characteristics and main findings of meta-analyses of observational studies reporting unique cancer and cardiovascular outcomes (direction of comparison is high versus low)

\begin{tabular}{|c|c|c|c|c|c|c|c|c|c|}
\hline Outcome & Biomarker & $\begin{array}{l}\text { Meta-analysis } \\
\text { metric }\end{array}$ & $\begin{array}{c}\text { No of } \\
\text { studies } \\
\text { in each } \\
\text { MA }\end{array}$ & $\begin{array}{l}\text { No of } \\
\text { events }\end{array}$ & Total No & $\begin{array}{l}\text { Relative risk (95\% } \\
\qquad \mathrm{Cl})^{\star}\end{array}$ & $P$ value & $\mathrm{I}^{2}(95 \% \mathrm{Cl})$ & $\begin{array}{l}\text { Egger test } \\
P \text { value }\end{array}$ \\
\hline \multicolumn{10}{|l|}{ Cancer outcomes } \\
\hline $\begin{array}{l}\text { Aggressive prostate } \\
\text { cancer }\end{array}$ & $25 \mathrm{OHD}$ & OR & 6 & 871 & 4524 & 0.98 (0.84 to 1.15$)$ & 0.81 & 33 (0 to 73 ) & 0.97 \\
\hline $\begin{array}{l}\text { Aggressive prostate } \\
\text { cancer }\end{array}$ & $1,25(\mathrm{OH}) 2 \mathrm{D}$ & OR & 2 & 696 & 1488 & 0.75 (0.48 to 1.17$)$ & 0.21 & $0(\mathrm{NA})$ & NA \\
\hline Breast cancer & $25 \mathrm{OHD}$ & OR & 21 & 11771 & 26317 & 0.55 (0.42 to 0.71$)$ & $1.0 \times 10^{-5}$ & 88 (83 to 91 ) & 0.06 \\
\hline Breast cancer & $1,25(\mathrm{OH}) 2 \mathrm{D}$ & OR & 3 & 1802 & 3627 & 0.99 (0.68 to 1.44$)$ & 0.96 & 47 (0 to 84 ) & 0.86 \\
\hline $\begin{array}{l}\text { Breast cancer: } \\
\text { postmenopausal }\end{array}$ & $25 \mathrm{OHD}$ & $\mathrm{RR}$ & 9 & 3929 & 8766 & 0.99 (0.97 to 1.01$)$ & 0.33 & 0 (0 to 54$)$ & 0.92 \\
\hline $\begin{array}{l}\text { Breast cancer: } \\
\text { premenopausal }\end{array}$ & $25 \mathrm{OHD}$ & $\mathrm{RR}$ & 6 & 1613 & 2890 & 1.01 (0.97 to 1.06$)$ & 0.67 & 37 (0 to 74$)$ & 0.76 \\
\hline Colon cancer & $25 \mathrm{OHD}$ & OR & 10 & 1822 & 4578 & 0.78 (0.56 to 1.07$)$ & 0.13 & 50 (0 to 74$)$ & 0.15 \\
\hline Colon cancer & $1,25(\mathrm{OH}) 2 \mathrm{D}$ & OR & 4 & No info & No info & 0.88 (0.57 to 1.35$)$ & 0.57 & NA & NA \\
\hline Colorectal cancer & $25 \mathrm{OHD}$ & $\mathrm{RR}$ & 10 & 2764 & 6712 & 0.70 (0.58 to 0.84$)$ & 0.0002 & 0 (0 to 53$)$ & 0.40 \\
\hline Colorectal cancer & $1,25(\mathrm{OH}) 2 \mathrm{D}$ & OR & 4 & No info & No info & 1.01 (0.59 to 1.73 ) & 0.97 & NA & NA \\
\hline Kidney cancer & $25 \mathrm{OHD}$ & OR & 6 & 740 & 1480 & 1.01 (0.65 to 1.58$)$ & 0.97 & $0(0$ to 61$)$ & 0.37 \\
\hline $\begin{array}{l}\text { Non-Hodgkin's } \\
\text { lymphoma (females) }\end{array}$ & $25 \mathrm{OHD}$ & OR & 4 & 18 & 39 & 0.81 (0.39 to 1.70$)$ & 0.59 & 0 (0 to 68$)$ & 0.56 \\
\hline $\begin{array}{l}\text { Non-Hodgkin's } \\
\text { lymphoma (males) }\end{array}$ & $25 \mathrm{OHD}$ & OR & 6 & 25 & 65 & 0.65 (0.35 to 1.23$)$ & 0.18 & $13(0$ to 66$)$ & 0.72 \\
\hline Ovarian cancer & $25 \mathrm{OHD}$ & OR & 10 & 884 & 2489 & 0.83 (0.63 to 1.09$)$ & 0.18 & $0(0$ to 53$)$ & 0.31 \\
\hline Pancreatic cancer & $25 \mathrm{OHD}$ & OR & 6 & 866 & 2113 & $2.13(1.02$ to 4.47$)$ & 0.04 & $17(0$ to 67$)$ & 0.90 \\
\hline Prostate cancer & $1,25(\mathrm{OH}) 2 \mathrm{D}$ & OR & 7 & 1361 & 3640 & $0.99(0.87$ to 1.14$)$ & 0.89 & $40(0$ to 74$)$ & 0.43 \\
\hline Prostate cancer & $25 \mathrm{OHD}$ & OR & 14 & 4353 & 28988 & 1.04 (0.98 to 1.09$)$ & 0.15 & 0 (0 to 47$)$ & 0.79 \\
\hline Rectal cancer & $25 \mathrm{OHD}$ & OR & 9 & 868 & 2050 & 0.50 (0.29 to 0.88$)$ & 0.01 & $51(0$ to 75$)$ & 0.10 \\
\hline $\begin{array}{l}\text { Sporadic colorectal } \\
\text { adenoma }\end{array}$ & $25 \mathrm{OHD}$ & OR & 9 & 2923 & 6268 & 0.82 (0.69 to 0.97$)$ & 0.02 & 66 (13 to 82$)$ & 0.34 \\
\hline $\begin{array}{l}\text { Sporadic colorectal } \\
\text { adenoma recurrence }\end{array}$ & $25 \mathrm{OHD}$ & OR & 3 & 586 & 1366 & 0.87 (0.57 to 1.33$)$ & 0.53 & 55 (0 to 86$)$ & 0.35 \\
\hline \multicolumn{10}{|c|}{ Cardiovascular outcomes } \\
\hline $\begin{array}{l}\text { Cardiovascular disease } \\
\text { (prevalent) }\end{array}$ & $25 \mathrm{OHD}$ & OR & 16 & 7600 & 64722 & 0.67 (0.55 to 0.82$)$ & $9.7 \times 10^{-5}$ & 74 (54 to 83 ) & 0.51 \\
\hline Cardiovascular disease & $25 \mathrm{OHD}$ & $\mathrm{RR}$ & 19 & 6123 & 66488 & 0.66 (0.57 to 0.77$)$ & $1.6 \times 10^{-7}$ & 61 (28 to 75 ) & 0.98 \\
\hline $\begin{array}{l}\text { Cardiovascular disease } \\
\text { mortality }\end{array}$ & $25 \mathrm{OHD}$ & $\mathrm{RR}$ & 5 & 2007 & 24387 & $0.55(0.36$ to 0.85$)$ & 0.006 & 81 (40 to 90$)$ & 0.09 \\
\hline Hypertension & $25 \mathrm{OHD}$ & $\mathrm{RR}$ & 7 & 4965 & 48633 & 0.70 (0.58 to 0.86$)$ & 0.0004 & 44 (0 to 75$)$ & 0.92 \\
\hline $\begin{array}{l}\text { Ischaemic heart } \\
\text { disease }\end{array}$ & $25 \mathrm{OHD}$ & $\mathrm{HR}$ & 19 & 8376 & 82982 & $0.72(0.65$ to 0.81$)$ & $4.1 \times 10^{-9}$ & 80 (69 to 86 ) & 0.27 \\
\hline Ischaemic stroke (HR) & $25 \mathrm{OHD}$ & $\mathrm{HR}$ & 4 & 1800 & 26596 & $0.66(0.55$ to 0.80$)$ & $2.1 \times 10^{-5}$ & 71 (0 to 86$)$ & 0.63 \\
\hline Ischaemic stroke (OR) & $25 \mathrm{OHD}$ & OR & 5 & 844 & 31858 & 0.52 (0.44 to 0.61$)$ & $2.3 \times 10^{-14}$ & 0 (0 to 64$)$ & 0.97 \\
\hline Stroke & $25 \mathrm{OHD}$ & $\mathrm{RR}$ & 7 & 1214 & 39095 & 0.61 (0.50 to 0.75$)$ & $1.8 \times 10^{-6}$ & $0(0$ to 58$)$ & 0.94 \\
\hline
\end{tabular}

$\mathrm{HR}=$ hazard ratio; $\mathrm{MA}=$ meta-analysis; $\mathrm{NA}=$ not applicable; $\mathrm{OR}=$ odds ratio; $\mathrm{RR}=$ relative risk.

$P$ values were estimated using formulas presented in Altman and Bland 2011. ${ }^{140}$

${ }^{*}$ Effect estimate and $95 \% \mathrm{Cl}$ estimated on basis of random effects model. Reported effect estimates and $95 \% \mathrm{Cl}$ are presented for colon cancer $(1,25(\mathrm{OH}) 2 \mathrm{D})$ and colorectal cancer $(1,25(\mathrm{OH}) 2 \mathrm{D})$. 
Table 2/ Characteristics and main findings of meta-analyses of observational studies reporting unique cognitive, infectious, metabolic, neonatal/infant/child related, pregnancy related, skeletal, and other outcomes (direction of comparison is high versus low)

\begin{tabular}{|c|c|c|c|c|c|c|c|c|c|c|}
\hline Outcome & Biomarker & $\begin{array}{c}\text { Meta-analysis } \\
\text { metric }\end{array}$ & Units & $\begin{array}{l}\text { No of } \\
\text { studies } \\
\text { in each } \\
\text { MA }\end{array}$ & $\begin{array}{l}\text { No of } \\
\text { events }\end{array}$ & Total No & $\begin{array}{l}\text { Relative risk }(95 \% \\
\qquad \mathrm{Cl})^{\star}\end{array}$ & $P$ value & $\mathrm{I}^{2}(95 \% \mathrm{Cl})$ & $\begin{array}{l}\text { Egger test } \\
P \text { value }\end{array}$ \\
\hline \multicolumn{11}{|l|}{ Cognitive disorders } \\
\hline Alzheimer's disease & $25 \mathrm{OHD}$ & SMD (to OR) & NA & 7 & 357 & 1005 & 0.08 (0.01 to 0.63$)$ & 0.02 & 98 (97 to 98$)$ & 0.32 \\
\hline Cognition & $25 \mathrm{OHD}$ & OR & NA & 7 & 1217 & 9004 & $0.42(0.34$ to 0.53$)$ & $2.2 \times 10^{-13}$ & 56 (0 to 79$)$ & 0.16 \\
\hline $\begin{array}{l}\text { Depression } \\
\text { (case-control } \\
\text { studies) } \\
\end{array}$ & $25 \mathrm{OHD}$ & OR & NA & 9 & 2051 & 19807 & 0.77 (0.59 to 1.00$)$ & 0.05 & $53(0$ to 76$)$ & 0.22 \\
\hline $\begin{array}{l}\text { Depression (cohort } \\
\text { studies) }\end{array}$ & $25 \mathrm{OHD}$ & $\mathrm{HR}$ & NA & 3 & 617 & 8815 & $0.44(0.27$ to 0.72$)$ & 0.001 & $28(0$ to 80$)$ & 0.49 \\
\hline \multicolumn{11}{|l|}{ Infectious diseases } \\
\hline Tuberculosis & $25 \mathrm{OHD}$ & SMD (to OR) & NA & 7 & 308 & 534 & $0.29(0.19$ to 0.46$)$ & $2.0 \times 10^{-7}$ & $41(0$ to 74$)$ & 0.79 \\
\hline \multicolumn{11}{|l|}{ Metabolic disorders } \\
\hline Body mass index & $25 \mathrm{OHD}$ & Z score & NA & 37 & NA & 16525 & $\begin{array}{c}-0.15(-0.19 \text { to } \\
-0.11)\end{array}$ & $8.9 \times 10^{-13}$ & NA & NA \\
\hline $\begin{array}{l}\text { Metabolic syndrome } \\
\text { (prevalent) }\end{array}$ & $25 \mathrm{OHD}$ & OR & NA & 8 & 2821 & 31416 & $0.49(0.38$ to 0.64$)$ & $1.4 \times 10^{-7}$ & $38(0$ to 71$)$ & 0.59 \\
\hline Type 2 diabetes & $25 \mathrm{OHD}$ & OR & NA & 16 & 4877 & 72204 & $0.63(0.56$ to 0.69$)$ & $5.0 \times 10^{-17}$ & $1(0$ to 46$)$ & 0.58 \\
\hline $\begin{array}{l}\text { Type } 2 \text { diabetes } \\
\text { (prevalent) }\end{array}$ & $25 \mathrm{OHD}$ & OR & NA & 9 & 2424 & 11892 & $0.45(0.25$ to 0.82$)$ & 0.008 & 79 (56 to 87$)$ & 0.96 \\
\hline \multicolumn{11}{|c|}{ Neonatal/infant/child related outcomes } \\
\hline Birth length & $25 \mathrm{OHD}$ & WMD & $\mathrm{cm}$ & 2 & NA & 840 & $\begin{array}{c}0.19(-0.26 \text { to } 0.65 \\
)\end{array}$ & 0.41 & NA & NA \\
\hline Birth weight & $25 \mathrm{OHD}$ & WMD & grams & 4 & NA & 5541 & $\begin{array}{c}130.9(75.1 \text { to } \\
186.7)\end{array}$ & $5.5 \times 10^{-6}$ & NA & NA \\
\hline Head circumference & $25 \mathrm{OHD}$ & WMD & $\mathrm{cm}$ & 2 & NA & 840 & $0.05(-0.24$ to 0.34$)$ & 0.76 & NA & NA \\
\hline $\begin{array}{l}\text { Small for gestational } \\
\text { age }\end{array}$ & $25 \mathrm{OHD}$ & OR & NA & 6 & NA & 6851 & $0.54(0.44$ to 0.67$)$ & $1.8 \times 10^{-8}$ & $8(0$ to 64$)$ & 0.81 \\
\hline \multicolumn{11}{|c|}{ Pregnancy related outcomes } \\
\hline Gestational diabetes & $25 \mathrm{OHD}$ & OR & NA & 10 & 687 & 4112 & $0.67(0.53$ to 0.85$)$ & 0.0009 & $0(0$ to 53$)$ & 0.58 \\
\hline Pre-eclampsia & $25 \mathrm{OHD}$ & OR & NA & 9 & 393 & 3230 & $0.56(0.39$ to 0.8$)$ & 0.002 & $0(0$ to 58$)$ & 0.96 \\
\hline \multicolumn{11}{|l|}{ Skeletal outcomes } \\
\hline Fractures & $25 \mathrm{OHD}$ & SMD (to OR) & NA & 28 & 1572 & 2956 & $0.31(0.23$ to 0.42$)$ & $1.3 \times 10^{-13}$ & 77 (66 to 83 ) & 0.78 \\
\hline $\begin{array}{l}\text { Hip fracture (hospital } \\
\text { based controls) }\end{array}$ & $25 \mathrm{OHD}$ & $\begin{array}{l}\text { log ratio of } \\
\text { geometric } \\
\text { mean }\end{array}$ & $\mathrm{nmol} / \mathrm{L}$ & 8 & 1116 & 2201 & $\begin{array}{c}-0.26(-0.33 \text { to } \\
-0.23)\end{array}$ & NA & NA & NA \\
\hline $\begin{array}{l}\text { Hip fracture } \\
\text { (population based } \\
\text { controls) }\end{array}$ & $25 \mathrm{OHD}$ & $\begin{array}{c}\text { log ratio of } \\
\text { geometric } \\
\text { mean }\end{array}$ & $\mathrm{nmol} / \mathrm{L}$ & 9 & 818 & 1655 & $\begin{array}{c}-0.51(-0.64 \text { to } \\
-0.38)\end{array}$ & NA & NA & NA \\
\hline \multicolumn{11}{|l|}{ Other outcomes } \\
\hline $\begin{array}{l}\text { All cause mortality } \\
\text { (in CKD patients) } \\
\end{array}$ & $25 \mathrm{OHD}$ & $\mathrm{RR}$ & NA & 10 & 2110 & 6853 & $0.86(0.81$ to 0.92$)$ & $4.6 \times 10^{-6}$ & $31(0$ to 66$)$ & 0.09 \\
\hline All cause mortality & $25 \mathrm{OHD}$ & $\mathrm{HR}$ & NA & 18 & 15447 & 77155 & 0.72 (0.66 to 0.78$)$ & $2.9 \times 10^{-13}$ & 82 (72 to 87$)$ & 0.29 \\
\hline
\end{tabular}

$\mathrm{CKD}=$ chronic kidney disease; $\mathrm{HR}=$ hazard ratio; $\mathrm{MA}=$ meta-analysis; $\mathrm{NA}=$ not applicable; $\mathrm{OR}=\mathrm{odds}$ ratio; $\mathrm{RR}=$ relative risk; $\mathrm{SMD}=$ standardised mean difference; WMD=weighted mean difference.

$P$ values were estimated using formulas presented in Altman and Bland $2011 .{ }^{140}$

*Effect estimate and $95 \% \mathrm{Cl}$ estimated based on random effects model. Reported effect estimates and $95 \% \mathrm{Cl}$ are presented for hip fracture (population based controls), hip fracture (hospital based controls), birth length, head circumference, and birth weight. 
Table 3| General characteristics of non-overlapping meta-analyses of randomised controlled trials of vitamin D supplementation for cardiovascular, metabolic, neonatal/infant/child related, pregnancy related, and other outcomes

\begin{tabular}{|c|c|c|c|c|c|c|c|}
\hline Outcome & Population & $\begin{array}{l}\text { Type of metric } \\
\text { (summary } \\
\text { effect) }\end{array}$ & Units & MA model & $\begin{array}{l}\text { No of } \\
\text { studies in } \\
\text { each MA }\end{array}$ & $\begin{array}{l}\text { Reported summary effect } \\
\qquad(95 \% \mathrm{Cl})\end{array}$ & $P$ value \\
\hline \multicolumn{8}{|l|}{ Cardiovascular outcomes } \\
\hline Cardiovascular disease & General & $\mathrm{RR}$ & NA & Fixed & 2 & 0.95 (0.86 to 1.05$)$ & 0.32 \\
\hline Diastolic blood pressure & $\begin{array}{l}\text { Normotensive or } \\
\text { hypertensive }\end{array}$ & WMD & $\mathrm{mm} \mathrm{Hg}$ & No info & 3 & $-0.03(-1.98$ to 1.92$)$ & 0.98 \\
\hline Systolic blood pressure & $\begin{array}{l}\text { Normotensive or } \\
\text { hypertensive }\end{array}$ & WMD & $\mathrm{mm} \mathrm{Hg}$ & No info & 3 & $-2.39(-5.7$ to 0.9$)$ & 0.16 \\
\hline \multicolumn{8}{|l|}{ Metabolic disorders } \\
\hline Fasting glucose & $\begin{array}{l}\text { Diabetes patients with } \\
\text { normal glucose } \\
\text { tolerance }\end{array}$ & WMD & $\mathrm{nmol} / \mathrm{L}$ & No info & No info & $0.01(-0.21$ to 0.23$)$ & 0.94 \\
\hline Fasting glucose & $\begin{array}{l}\text { Diabetes patients with } \\
\text { abnormal glucose } \\
\text { tolerance }\end{array}$ & WMD & $\mathrm{nmol} / \mathrm{L}$ & No info & No info & $-0.3(-0.9$ to 0.3$)$ & 0.33 \\
\hline High density lipoprotein & General & WMD & $\mathrm{mg} / \mathrm{dL}$ & Fixed & 8 & $-0.14(-0.99$ to 0.71$)$ & 0.76 \\
\hline Insulin resistance & Diabetes & SMD & NA & No info & 5 & $0.16(-0.11$ to 0.42$)$ & 0.24 \\
\hline Total cholesterol & General & WMD & $\mathrm{mg} / \mathrm{dL}$ & Fixed & 11 & $1.52(-1.42$ to 4.46$)$ & 0.32 \\
\hline Low density lipoprotein & General & WMD & $\mathrm{mg} / \mathrm{dL}$ & Fixed & 7 & $3.23(0.55$ to 5.9$)$ & 0.02 \\
\hline Triglycerides & General & WMD & $\mathrm{mg} / \mathrm{dL}$ & Fixed & 8 & $-1.92(-7.72$ to 3.88$)$ & 0.53 \\
\hline \multicolumn{8}{|c|}{ Neonatal/infant/child related outcomes } \\
\hline Birth length & Pregnant women & WMD & $\mathrm{cm}$ & Random & 2 & $0.97(-0.41$ to 2.34$)$ & 0.17 \\
\hline Low birth weight & Pregnant women & $\mathrm{RR}$ & NA & Fixed & 3 & $0.4(0.23$ to 0.71$)$ & 0.001 \\
\hline Dental caries & Children & $\mathrm{RR}$ & NA & Random & 38 & 0.53 (0.43 to 0.65$)$ & $3.7 \times 10^{-9}$ \\
\hline Head circumference at birth & Pregnant women & WMD & $\mathrm{cm}$ & Random & 2 & $0.43(0.06$ to 0.79$)$ & 0.02 \\
\hline Small for gestational age & Pregnant women & $\mathrm{RR}$ & NA & Fixed & 2 & $0.67(0.40$ to 1.11$)$ & 0.12 \\
\hline \multicolumn{8}{|c|}{ Pregnancy related outcomes } \\
\hline $\begin{array}{l}\text { Maternal vitamin } \mathrm{D} \\
\text { concentrations at term }\end{array}$ & Pregnant women & WMD & $\mathrm{nmol} / \mathrm{L}$ & Random & 4 & 47.08 (23.76 to 70.39 ) & $8.7 \times 10^{-5}$ \\
\hline $\begin{array}{l}\text { Mean gestational age at } \\
\text { delivery }\end{array}$ & Pregnant women & WMD & Weeks & Fixed & 2 & $0.17(-0.16$ to 0.51$)$ & 0.32 \\
\hline Preterm delivery & Pregnant women & $\mathrm{RR}$ & NA & Fixed & 2 & $0.77(0.35$ to 1.66$)$ & 0.52 \\
\hline \multicolumn{8}{|l|}{ Other outcomes } \\
\hline Alkaline phosphatase & CKD NRD & WMD & $\mathrm{U} / \mathrm{L}$ & Fixed & 2 & -21.81 (-40.39 to 3.22$)$ & 0.06 \\
\hline Alkaline phosphatase & CKD RD & WMD & $\mathrm{U} / \mathrm{L}$ & Fixed & 3 & $-27.35(-50.69$ to -4.01$)$ & 0.02 \\
\hline Creatinine clearance & CKD NRD & WMD & $\mathrm{mL} / \mathrm{min}$ & Fixed & 4 & $-1.68(-6.92$ to 3.56$)$ & 0.54 \\
\hline Mortality & General (vitamin $D_{3}$ ) & $\mathrm{RR}$ & NA & Random & 9 & 0.91 (0.82 to 1.02$)$ & 0.09 \\
\hline Mortality & General (vitamin $D_{2}$ ) & $\mathrm{RR}$ & NA & Random & 8 & $1.04(0.97$ to 1.11$)$ & 0.26 \\
\hline Mortality & CKD NRD & $\mathrm{RR}$ & NA & Fixed & 4 & $1.40(0.38$ to 5.15$)$ & 0.63 \\
\hline Mortality & CKD RD & $\mathrm{RR}$ & NA & Fixed & 5 & 1.34 (0.34 to 5.24$)$ & 0.69 \\
\hline Parathyroid hormone & CKD NRD & WMD & $\mathrm{pmol} / \mathrm{L}$ & Fixed & 4 & $-49.34(-85.70$ to -12.97$)$ & 0.008 \\
\hline Parathyroid hormone & CKD RD & WMD & $\mathrm{pmol} / \mathrm{L}$ & Fixed & 6 & $-196.05(-298.43$ to -93.66$)$ & 0.0002 \\
\hline Parathyroidectomy & CKD RD & $\mathrm{RR}$ & NA & Fixed & 2 & $0.82(0.05$ to 12.47$)$ & 0.90 \\
\hline Risk of hypercalcaemia & CKD NRD & $\mathrm{RR}$ & NA & Fixed & 7 & 3.04 (1.17 to 7.90$)$ & 0.02 \\
\hline Risk of hypercalcaemia & CKD RD & $\mathrm{RR}$ & NA & Fixed & 5 & 3.80 (0.90 to 16.12$)$ & 0.07 \\
\hline Risk of hyperphosphataemia & CKD NRD & $\mathrm{RR}$ & NA & Fixed & 2 & $1.58(0.47$ to 5.30$)$ & 0.47 \\
\hline Risk of hyperphosphataemia & CKD RD & $\mathrm{RR}$ & NA & Fixed & 2 & 1.57 (0.97 to 2.54$)$ & 0.07 \\
\hline Risk of requiring dialysis & CKD NRD & $\mathrm{RR}$ & NA & Fixed & 4 & $0.76(0.36$ to 1.62$)$ & 0.48 \\
\hline Subperiosteal erosions & CKD RD & $\mathrm{RR}$ & NA & Fixed & 3 & 0.41 (0.07 to 2.38$)$ & 0.33 \\
\hline Vascular calcification & CKD RD & $\mathrm{RR}$ & NA & Fixed & 2 & 1.09 (0.45 to 2.67$)$ & 0.86 \\
\hline
\end{tabular}


Table 3 (continued)

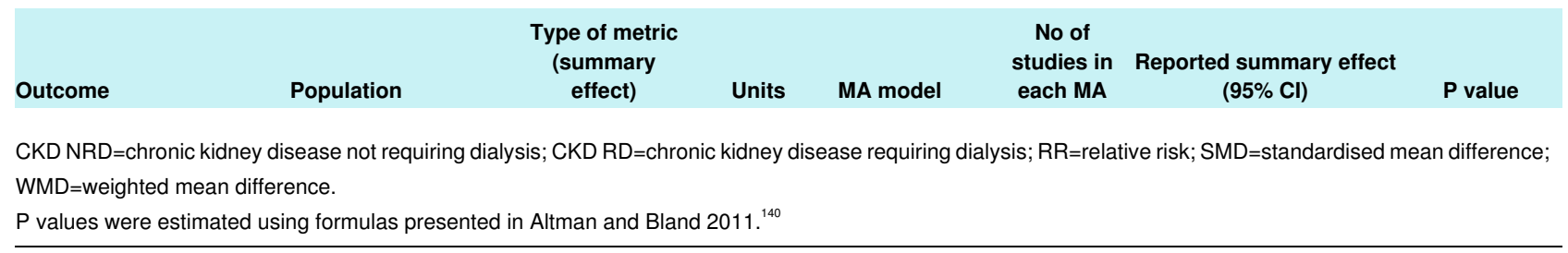


Table 4 | General characteristics of non-overlapping meta-analyses of randomised controlled trials of vitamin D supplementation for skeletal outcomes

\begin{tabular}{|c|c|c|c|c|c|c|c|}
\hline Skeletal outcome & Population & $\begin{array}{l}\text { Type of metric } \\
\text { (summary } \\
\text { effect) }\end{array}$ & Units & MA model & $\begin{array}{c}\text { No of } \\
\text { studies in } \\
\text { each MA }\end{array}$ & $\begin{array}{l}\text { Reported summary } \\
\text { effect }(95 \% \mathrm{Cl})\end{array}$ & $P$ value \\
\hline Bone mineral density & Healthy children & SMD & $\%$ change & Fixed & 5 & $0.1(-0.06$ to 0.26$)$ & 0.22 \\
\hline Bone mineral density & Community dwelling adults & WMD & $\%$ change & Random & 3 & $-0.9(-2.10$ to 0.40$)$ & 0.16 \\
\hline $\begin{array}{l}\text { Bone mineral density in } \\
\text { femoral neck }\end{array}$ & Community dwelling adults & WMD & $\%$ change & Random & 8 & $1.10(0.40$ to 1.90$)$ & 0.004 \\
\hline $\begin{array}{l}\text { Bone mineral density in } \\
\text { forearm }\end{array}$ & Community dwelling adults & WMD & $\%$ change & Random & 2 & $-0.70(1.70$ to 0.40$)$ & 0.19 \\
\hline $\begin{array}{l}\text { Bone mineral density in } \\
\text { forearm }\end{array}$ & Healthy children & SMD & $\%$ change & Random & 3 & 0.04 (-0.36 to 0.45$)$ & 0.86 \\
\hline Bone mineral density in hip & Healthy children & SMD & $\%$ change & Random & 4 & $0.06(-0.18$ to 0.29$)$ & 0.63 \\
\hline Bone mineral density in hip & Community dwelling adults & WMD & $\%$ change & Random & 6 & $0.70(-0.10$ to 1.60$)$ & 0.11 \\
\hline $\begin{array}{l}\text { Bone mineral density in } \\
\text { lumbar spine }\end{array}$ & Healthy children & SMD & $\%$ change & Fixed & 5 & 0.15 (-0.01 to 0.31$)$ & 0.07 \\
\hline $\begin{array}{l}\text { Bone mineral density in } \\
\text { lumbar spine }\end{array}$ & Community dwelling adults & WMD & $\%$ change & Random & 7 & $0.10(-0.60$ to 0.70$)$ & 0.78 \\
\hline Bone pain & CKD RD & $\mathrm{RR}$ & NA & Fixed & 4 & 0.29 (0.03 to 2.63$)$ & 0.28 \\
\hline Falls & Older adults & OR & NA & Random & 10 & 0.97 (0.84 to 1.11$)$ & 0.68 \\
\hline Falls: rate of falls & $\begin{array}{l}\text { Older people in care } \\
\text { facilities or hospitals }\end{array}$ & RaR & NA & Random & 2 & 0.55 (0.19 to 1.64$)$ & 0.28 \\
\hline Falls: rate of falls & Older people in community & RaR & NA & Random & 2 & 1.14 (1.03 to 1.27$)$ & 0.01 \\
\hline Fractures & $\begin{array}{l}\text { Men aged }>65 \text { years and } \\
\text { postmenopausal women }\end{array}$ & $\mathrm{RR}$ & NA & Fixed & 10 & 1.01 (0.93 to 1.09$)$ & 0.82 \\
\hline Fractures & CKD RD & $\mathrm{RR}$ & NA & Fixed & 4 & $1.00(0.06$ to 15.41$)$ & 1.00 \\
\hline Fractures: hip & $\begin{array}{l}\text { Men aged }>65 \text { years and } \\
\text { postmenopausal women }\end{array}$ & $\mathrm{RR}$ & NA & Fixed & 9 & 1.15 (0.99 to 1.33$)$ & 0.06 \\
\hline Fractures: non-vertebral & People aged $>65$ years & $\mathrm{RR}$ & NA & No info & 5 & 0.79 (0.63 to 0.99$)$ & 0.04 \\
\hline $\begin{array}{l}\text { Fractures: non-vertebral, } \\
\text { non-hip }\end{array}$ & Older women & OR & NA & Random & 2 & 0.69 (0.21 to 1.66$)$ & 0.49 \\
\hline $\begin{array}{l}\text { Fractures: vertebral or } \\
\text { deformity }\end{array}$ & $\begin{array}{l}\text { Men aged }>65 \text { years and } \\
\text { postmenopausal women }\end{array}$ & $\mathrm{RR}$ & NA & Random & 5 & 0.90 (0.42 to 1.92$)$ & 0.80 \\
\hline $\begin{array}{l}\text { Performance measures: } \\
\text { balance sway }\end{array}$ & Older adults & SMD & NA & Fixed & 3 & $-0.20(-0.39$ to -0.01$)$ & 0.04 \\
\hline $\begin{array}{l}\text { Performance measures: } \\
\text { lower extremity strength }\end{array}$ & Older adults & SMD & NA & Fixed & 3 & $0.05(-0.11$ to 0.20$)$ & 0.54 \\
\hline $\begin{array}{l}\text { Performance measures: } \\
\text { muscle strength }\end{array}$ & Older adults & SMD & NA & Fixed & 3 & $-0.19(-0.35$ to -0.02$)$ & 0.02 \\
\hline
\end{tabular}

$\mathrm{CKD} R \mathrm{RD}=$ chronic kidney disease requiring dialysis; $\mathrm{OR}=\mathrm{odds}$ ratio; $\mathrm{RaR}=$ rate ratio; $\mathrm{RR}=$ relative risk; $\mathrm{SMD}=$ standardised mean difference; $\mathrm{WMD}=$ weighted mean difference.

$\mathrm{P}$ values were estimated using formulas presented in Altman and Bland 2011. ${ }^{140}$ 
Table 5| Overlap between meta-analyses of observational studies and vitamin D supplementation randomised controlled trials

\begin{tabular}{|c|c|c|c|c|c|c|c|}
\hline \multirow[b]{2}{*}{ Disease outcome } & \multicolumn{2}{|c|}{ Observational } & \multicolumn{2}{|c|}{ Randomised controlled trials } & \multirow[b]{2}{*}{$\begin{array}{c}\text { Concordant } \\
\text { direction }\end{array}$} & \multicolumn{2}{|c|}{$\mathrm{Cl}$ excluded null } \\
\hline & Metric & Effect size $(95 \% \mathrm{Cl})$ & Metric & Effect size $(95 \% \mathrm{Cl})$ & & Both & $\begin{array}{l}\text { Observational } \\
\text { only }\end{array}$ \\
\hline Cardiovascular disease $e^{102130}$ & OR & 0.66 (0.57 to 0.77$)$ & OR & 0.95 (0.86 to 1.05$)$ & Yes & No & Yes \\
\hline $\begin{array}{l}\text { Hypertension/blood } \\
\text { pressure }^{104127}\end{array}$ & OR & 0.70 (0.58 to 0.86$)$ & WMD & $-2.39(-5.7$ to 1.92$)$ & Yes & No & Yes \\
\hline $\begin{array}{l}\text { Birth weight/ risk of low birth } \\
\text { weight }^{3661}\end{array}$ & WMD & $130.9(75.1$ to 186.7$)$ & OR & $0.4(0.23$ to 0.71$)$ & Yes & Yes & No \\
\hline Birth length ${ }^{36} 112$ & WMD & $0.19(-0.26$ to 0.65$)$ & WMD & $0.97(-0.41$ to 2.34$)$ & Yes & No & No \\
\hline Head circumference ${ }^{36112}$ & WMD & $0.05(-0.24$ to 0.34$)$ & WMD & $0.43(0.06$ to 0.79$)$ & Yes & No & No \\
\hline Small for gestational age $\mathrm{ag}^{3661}$ & OR & 0.54 (0.44 to 0.67$)$ & OR & $0.67(0.4$ to 1.11$)$ & Yes & No & Yes \\
\hline Mortality in CKD patients ${ }^{84120}$ & OR & 0.86 (0.81 to 0.92$)$ & OR & $1.4(0.38$ to 5.15$)$ & No & No & Yes \\
\hline All cause mortality ${ }^{66110}$ & OR & $0.72(0.66$ to 0.78$)$ & OR & 0.91 (0.82 to 1.02$)$ & Yes & No & Yes \\
\hline $\begin{array}{l}\text { Fractures in older } \\
\text { populations }^{91107}\end{array}$ & OR & 0.31 (0.23 to 0.42$)$ & OR & 1.01 (0.93 to 1.09$)$ & No & No & Yes \\
\hline Hip fracture ${ }^{37} 107$ & $\begin{array}{l}\text { Log ratio of } \\
\text { geometric mean }\end{array}$ & $-0.26(-0.33$ to -0.23$)$ & OR & 1.15 (0.99 to 1.33$)$ & No & No & Yes \\
\hline
\end{tabular}

$\mathrm{Cl}=$ confidence interval; $\mathrm{CKD}=$ chronic kidney disease; $\mathrm{OR}=$ odds ratio; $\mathrm{WMD}=$ weighted mean difference. 


\begin{tabular}{|c|c|c|}
\hline Evidence category ${ }^{*}$ & Health benefits & Heath risks \\
\hline Convincing & None & None \\
\hline \multirow[t]{3}{*}{ Probable } & Decreases risk of dental caries in children & \multirow[t]{3}{*}{ None } \\
\hline & Increases levels of birth weight and maternal vitamin D concentrations at term & \\
\hline & Decreases levels of parathyroid hormone concentrations in CKD RD & \\
\hline \multirow[t]{3}{*}{ Suggestive } & $\begin{array}{l}\text { Decreases risk of colorectal cancer, non-vertebral fractures, CVD, CVD prevalence, hypertension, ischaemic stroke, } \\
\text { stroke, cognition, depression (cohort studies), body mass index, metabolic syndrome prevalence, type } 2 \text { diabetes, } \\
\text { small for gestational age birth, gestational diabetes mellitus }\end{array}$ & \multirow{3}{*}{$\begin{array}{l}\text { Increases rate of falls } \\
\text { (community) and risk } \\
\text { of hypercalcaemia in } \\
\text { CKD NRD }\end{array}$} \\
\hline & $\begin{array}{l}\text { Decreases levels of balance sway, alkaline phosphatase concentrations in CKD RD, parathyroid hormone } \\
\text { concentrations in CKD NRD }\end{array}$ & \\
\hline & Increases levels of head circumference at birth, LDL, bone mineral density in femoral neck, muscle strength & \\
\hline \multirow[t]{3}{*}{ No conclusion } & $\begin{array}{l}\text { Decreases risk of ankylosing spondylitis, Crohn's disease, multiple sclerosis, osteoarthritis, rheumatoid arthritis, } \\
\text { rheumatoid arthritis activity, scleroderma, systemic lupus erythematosus, thyroid autoimmunity, type } 1 \text { diabetes, } \\
\text { type } 1 \text { diabetes in childhood (maternal vitamin D status), vitiligo, breast cancer, breast cancer prognosis, colon } \\
\text { cancer, colorectal adenoma, colorectal adenoma recurrence, colorectal cancer prognosis, lung cancer, melanoma } \\
\text { prognosis, non-Hodgkin's lymphoma, non-small cell lung cancer prognosis, oesophageal cancer, ovarian cancer, } \\
\text { prostate cancer prognosis, rectal cancer, renal cancer, stomach cancer, CVD in ethnic minorities, CVD mortality, } \\
\text { hypertension in children, ischaemic heart disease, myocardial infarction, Alzheimer's disease, depression (case-control } \\
\text { studies), active tuberculosis, acute respiratory infection, infectious disease mortality, metabolic syndrome in ethnic } \\
\text { minorities, obesity in ethnic minorities, type } 2 \text { diabetes in ethnic minorities, type } 2 \text { diabetes prevalence, allergic } \\
\text { rhinitis and atopic dermatitis/eczema (maternal vitamin D status), cerebral function and diseases (maternal vitamin } \\
\text { D status), childhood infections (maternal vitamin D status), wheezing and asthma in childhood (maternal vitamin D } \\
\text { status), bacterial vaginosis in pregnant women, fertility, postpartum depression, pre-eclampsia in pregnant women, } \\
\text { pregnancy associated breast cancer, bone health in pregnant and lactating women, bone pain in CKD RD, falls, } \\
\text { rate of falls (care facilities), fractures in older people, fractures in CKD RD, hip fractures, non-vertebral non-hip } \\
\text { fractures, vertebral fractures or deformity, performance measures in older people, rickets in children, all cause } \\
\text { mortality, mortality in CKD, risk of requiring dialysis in CKD NRD, parathyroidectomy in CKD RD, subperiosteal } \\
\text { erosions in CKD RD, mammographic breast density }\end{array}$ & \multirow[t]{3}{*}{$\begin{array}{l}\text { Increases risk of } \\
\text { pancreatic cancer, } \\
\text { hyperphosphataemia } \\
\text { in CKD, vascular } \\
\text { calcification in CKD } \\
\text { RD, hypercalcaemia in } \\
\text { CKD RD }\end{array}$} \\
\hline & $\begin{array}{l}\text { Decreases levels of HDL in children, } \mathrm{LDL} \text { in children, triglycerides in children, insulin/glucose metabolism in children, } \\
\text { triglycerides, insulin resistance of diabetes patients, bone mineral density, bone mineral density in forearm, alkaline } \\
\text { phosphatase concentrations in CKD NRD, creatinine clearance in CKD }\end{array}$ & \\
\hline & $\begin{array}{l}\text { Increases levels of total cholesterol concentrations, neonatal and infant growth, length of gestation, bone mineral } \\
\text { content in infants, bone mineral density in hip, bone mineral density in lumbar spine (children) }\end{array}$ & \\
\hline \multirow[t]{3}{*}{$\begin{array}{l}\text { Substantial effect } \\
\text { unlikely }\end{array}$} & $\begin{array}{l}\text { Decreases risk of aggressive prostate cancer, premenopausal breast cancer, postmenopausal breast cancer, cancer } \\
\text { mortality, kidney cancer, prostate cancer, caesarean section }\end{array}$ & \multirow[t]{3}{*}{ None } \\
\hline & Decreases levels of fasting glucose in diabetes patients, HDL, adiposity in children (maternal vitamin D status) & \\
\hline & $\begin{array}{l}\text { Increases levels of birth length (maternal vitamin D status), bone mineral density in children, bone mineral density } \\
\text { in forearm in children, bone mineral density in hip in children, bone mineral density in lumbar spine, lower extremity } \\
\text { strength }\end{array}$ & \\
\hline
\end{tabular}

$\mathrm{CKD}=$ chronic kidney disease; $\mathrm{CVD}=$ cardiovascular disease; $\mathrm{HDL}=$ high density lipoprotein; $\mathrm{LDL}=$ low density lipoprotein; $\mathrm{NRD=not}$ requiring dialysis; $\mathrm{RD}=$ requiring dialysis.

*See box. 


\section{Figures}

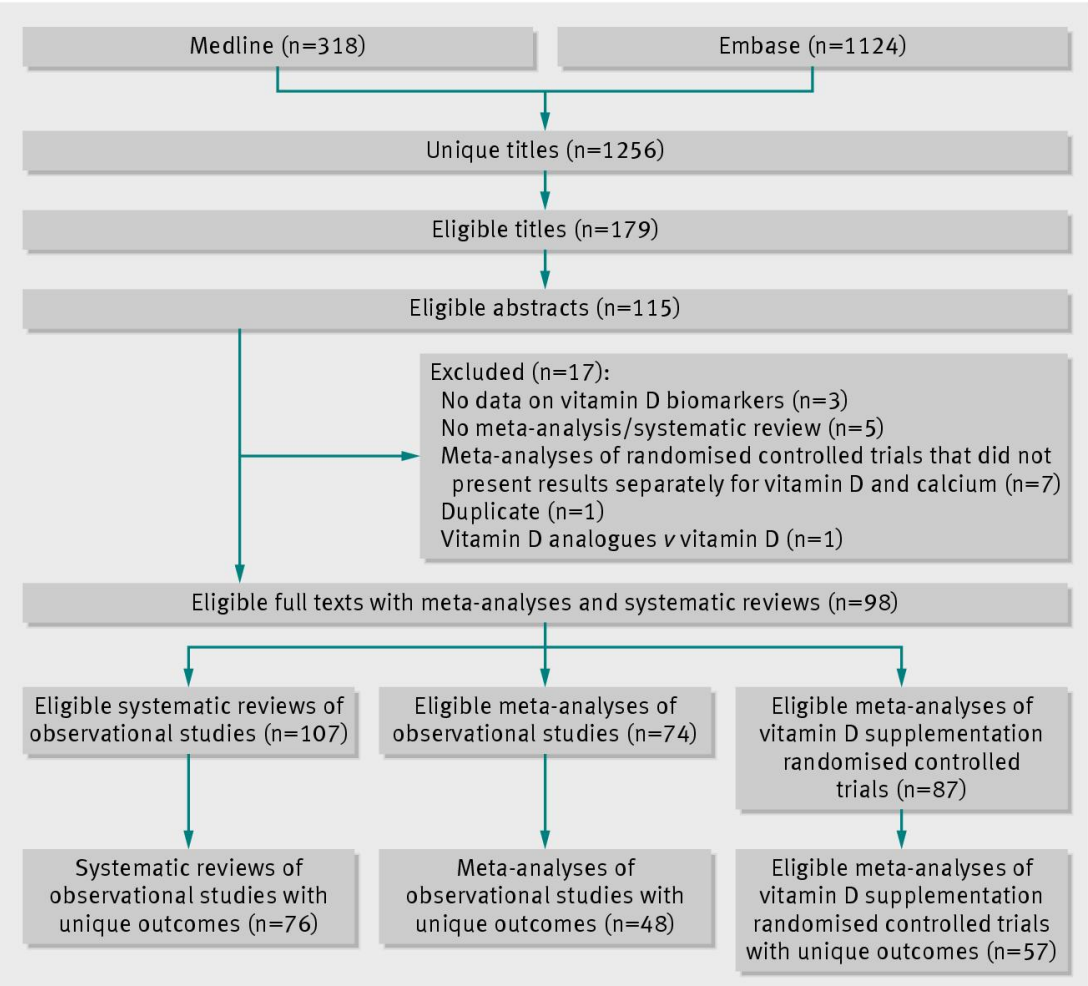

Fig 1 Flow chart of eligible studies

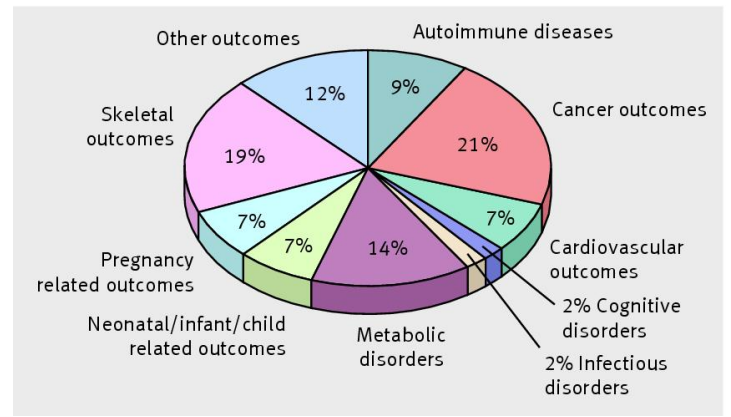

Fig 2 Map of 137 vitamin D related outcomes: percentage of outcomes per outcome category for all study designs 


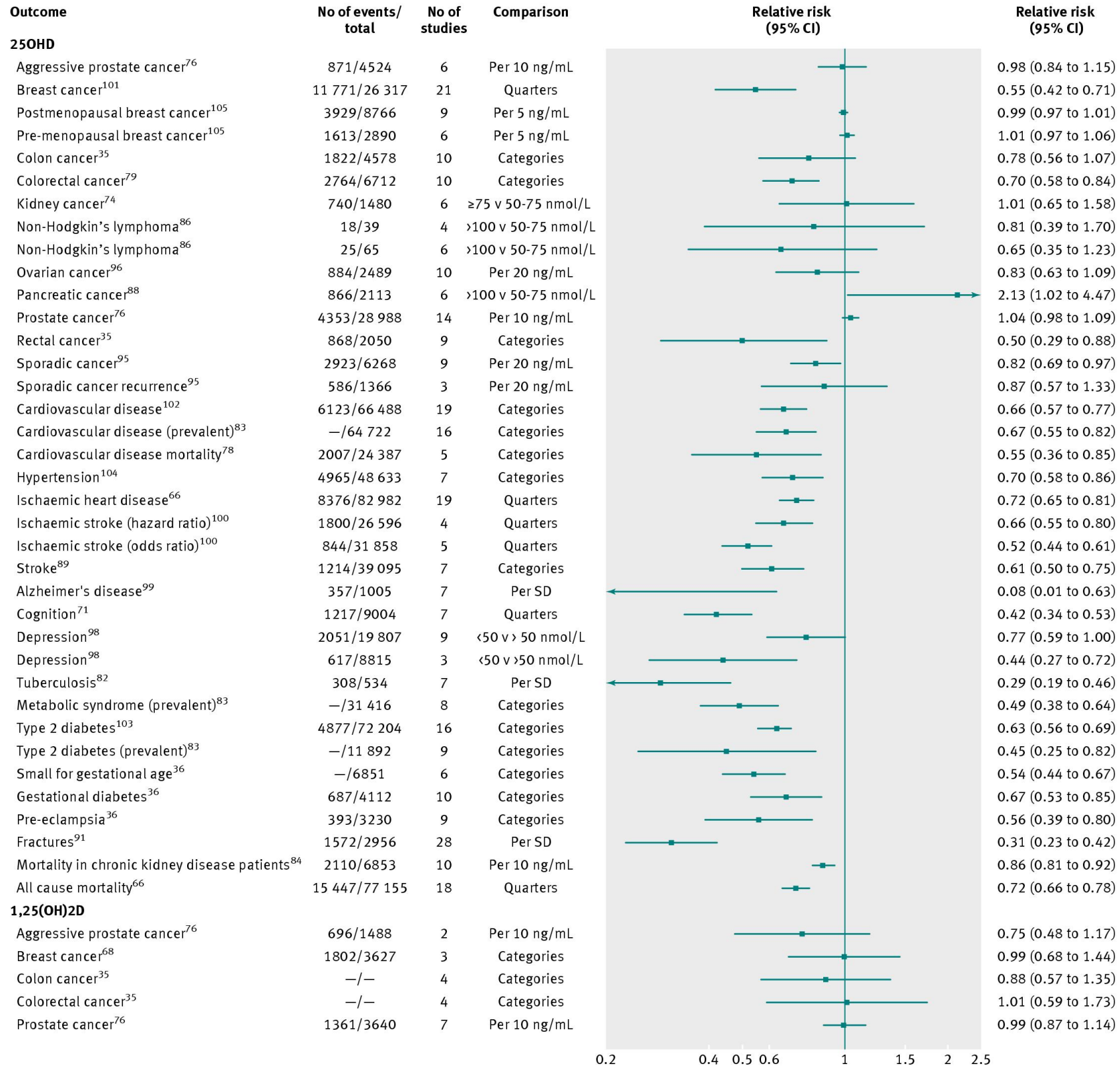

Fig 3 Forest plot of all meta-analyses of observational studies stratified by measured biomarker with relative risk as type of metric 


\section{Outcome}

\section{Vitamin D}

Cardiovascular disease ${ }^{130}$ Low birth weight ${ }^{61}$

Small for gestational age ${ }^{61}$

Preterm delivery ${ }^{61}$

Bone pain in CKD patients ${ }^{121}$

Fractures in CKD RD ${ }^{121}$

Mortality (CKD NRD) $)^{120}$

Mortality (CKD RD) ${ }^{121}$

Parathyroidectomy (CKD RD) ${ }^{121}$

Risk of hypercalcaemia (CKD NRD) ${ }^{120}$

Risk of hypercalcaemia (CKD RD) ${ }^{121}$

Risk of hyperphosphataemia (CKD NRD) ${ }^{12}$

Risk of hyperphosphataemia (CKD RD) ${ }^{121}$

Risk of requiring dialysis (CKD NRD) ${ }^{120}$

Subperiosteal erosions (CKD RD) ${ }^{121}$

Vascular calcification (CKD RD) ${ }^{121}$

Vitamin $D_{2}$ or $D_{3}$ or UV therapy

Dental caries $^{128}$

Vitamin $\mathbf{D}_{2}$ or $\mathbf{D}_{\mathbf{3}}$ or active $\mathrm{D}$ (or + calcium)

Non-vertebral fractures

\section{Vitamin $\mathbf{D}_{3}$}

Mortality ${ }^{110}$

Vitamin $D_{2}, D_{3}$ or D

Fractures ${ }^{107}$

Hip fractures ${ }^{107}$

Vertebral fractures ${ }^{107}$

Vitamin $\mathbf{D}_{2}$

Mortality ${ }^{110}$

\section{Participants Studies}

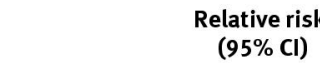

$(95 \% \mathrm{Cl})$

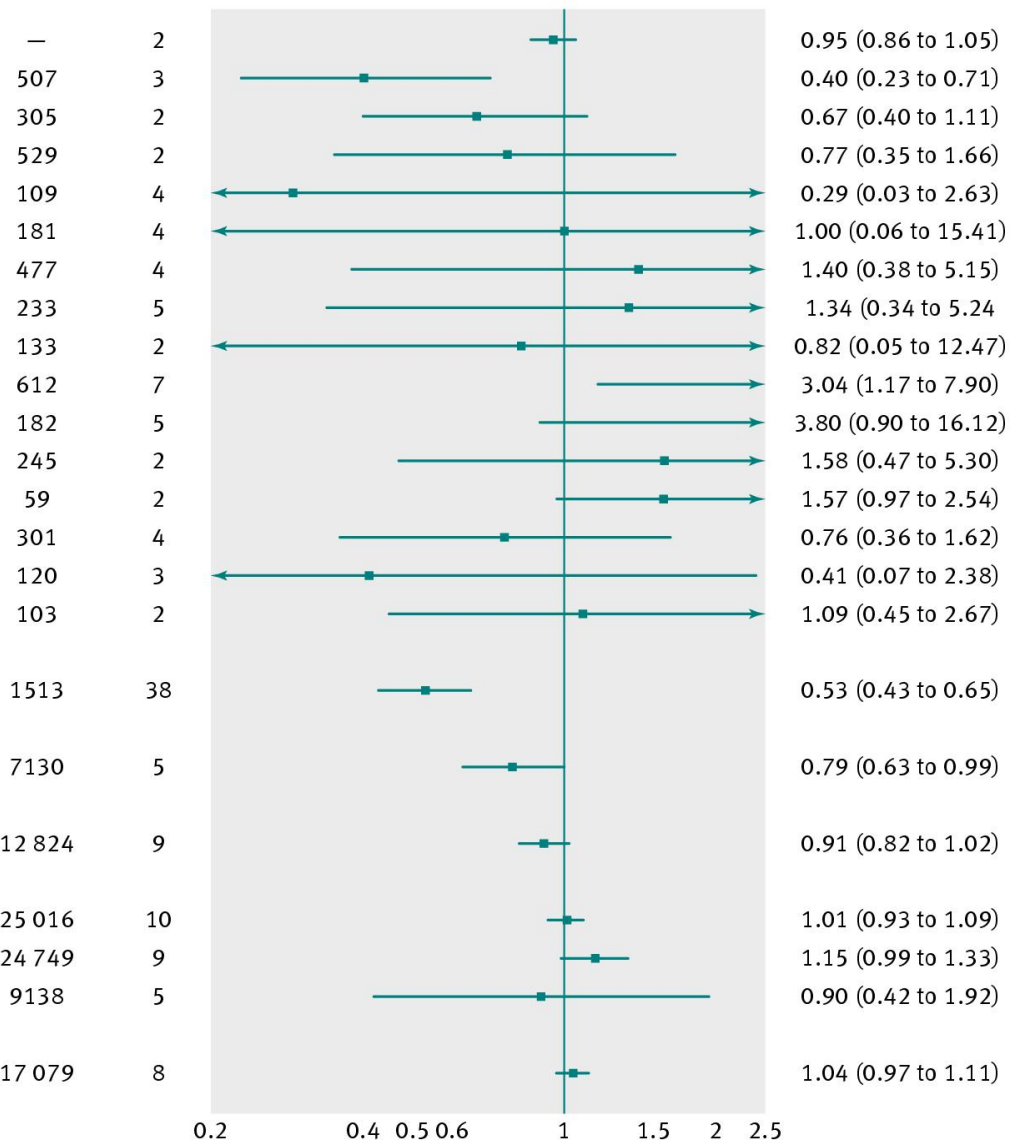

Fig 4 Forest plot of all meta-analyses of randomised controlled trials with relative risk as type of metric by compound administered. $\mathrm{CKD}=$ chronic kidney disease patients; $\mathrm{NRD}=$ not requiring dialysis; $\mathrm{RD}=$ requiring dialysis; $\mathrm{UV}=u$ ultraviolet 